\title{
NOTICE
}

THE LATEST VERSION OF THIS WORKING PAPER HAS BEEN PUBLISHED IN

\section{HISTORY OF TECHNOLOGY}

\author{
AS \\ SAIZ, Patricio (2002): “The Spanish Patent System (1770-1907", \\ History of Technology 24: 45-79.
}

See

http://www.bloomsbury.com/us/history-of-technology9780826471864/

or contact patricio.saiz@uam.es for further information 
I.S.S.N: 1885-6888

\title{
ECONOMIC HISTORY
}

\section{WORKING PAPER SERIES}

\author{
THE SPANISH PATENT SYSTEM. \\ ORIGINS, CHARACTERISTICS AND EVOLUTION \\ Patricio Sáiz \\ Working Paper 01/2002
}

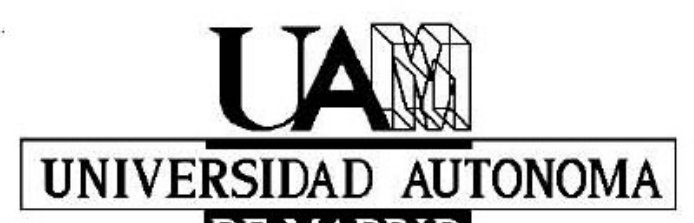

DE MADRID

\section{DEPARTAMENTO DE ANÁLI SI S ECONÓMI CO: TEORÍ A ECONÓMI CA E HI STORI A ECONÓMI CA}




\title{
The Spanish Patent System Origins, Characteristics and Evolution* .
}

\author{
J. Patricio Sáiz González \\ Universidad Autónoma de Madrid
}

\section{Introduction}

The influence of processes of innovation and technical change on economic growth is unquestioned by most economists and economic historians. However, the analysis of the forces and mechanisms that connected them has been a major topic of debate and controversy in the specialized literature. Hence, in several of the first and most well known theoretical constructs in this respect, such as those of Schumpeter or Kuznets, the variations in growth cycles were explained as a function of the changes in the adoption and diffusion of innovations ${ }^{1}$. From this vantage point, inventive activity became fundamentally a problem of supply, which, upon its introduction in the processes of production on the part of restless entrepreneurs, led to 'clusters' of innovations and towards industrial expansion. From the opposite perspective, at the beginning of the 1960's, J. Schmookler formulated the idea that it was the demand for technical solutions in the growing production sectors that was the ultimate origin of the processes of invention and innovation, and sparked the debate within the framework of economic rationality. In order to do that, Schmookler attempted to demonstrate how inventions measured by patents followed production in certain American industries ${ }^{2}$. Later, other researchers, such as N. Rosenberg, or even J. Mokyr, attempted to reconcile both questions, since, without denying the role of demand in influencing the rhythm and direction of the invention and innovation processes, they pointed out that this was produced within the limits of scientific and technological supply, which did not advance equally in all disciplines ${ }^{3}$.

These three main lines of theoretical argumentation have obviously been studied, detailed and developed by many other authors who have contributed to enriching, diversifying and endogenizing the debate ${ }^{4}$. Each in their own way have shed light upon the systems of interaction between technical change and economic growth, and collectively, have reinforced the idea of the existence of complex links, processes of feed-back and institutional conditioning in the complicated relationship between technology and economy. Especially among historians, mid- and long-term reflections on technological change and economic growth have occupied thousands of pages not easily summed up; from general works ${ }^{5}$ to approximations focussed on concrete processes of national modernization, not to mention the numerous examples of sectorial or regional studies in which the analysis of technology takes a prominent place. These types of studies of an historical nature have allowed an in-depth debate ${ }^{6}$. But, in general, what we would like to point out here is that most of this historic research -centred on mid- and long term analysis- on the processes of invention, innovation, technological change and economic growth has had two common denominators: a) interest in models of economically more developed pioneering countries or followers and b) the use of series of patents as a technological indicator.

With respect to the first focus, beyond pointing out that research on technological change and growth has been centred on the leading capitalist countries,

\footnotetext{
* This work has been finally published in: SAIZ, J. Patricio: “The Spanish Patent System (1770-1907”, History of Technology, vol. 24, 2002, pp. 45-79.
} 
we would like to emphasize the lack of studies on underdeveloped countries, those latecomers, a study of which would allow us to follow their development and the characteristics of their systems of innovation, what type of institutional changes they experienced and how these influenced the processes of modernization and growth (whether or not they experienced stages similar to their predecessors). Thereby we might uncover what the analysis of undeveloped systems adds to the previous debate on the relationship between technology and economic development. With respect to the second point -the use of patents- it appears to be obvious that in the absence of real data, sufficiently broken down, on inventive and innovative activity in different economies, it has been necessary to fall back on indirect indicators; that is, with the impossibility of measuring all technologies and organizational changes incorporated in the production process, as well as other questions related to the training of human capital and know-how, most researchers have used the information contained in patents as a substitute, although other systems have also appeared -in general much more limited and imperfect- based on the analysis of R \& D expenditures ${ }^{7}$, of changes in productivity $^{8}$, of scientific publications ${ }^{9}$ or, even of international industrial expositions ${ }^{10}$.

In fact, the object of this study is to use documentation on patents as a partial technology indicator, and, above all, as an investment indicator in new technologies ${ }^{11}$ in order to analyze the formation, evolution and characterization of the Spanish technological system during the $19^{\text {th }}$ and the beginning of the $20^{\text {th }}$ centuries. From our point of view, ceteris paribus, the decision to patent is based on the intuitive expectation of profits with the new technology -which is influenced both by economic growth itself and by marketing possibilities, as well as by institutional questions, such as the real possibility of enforcing the patent monopoly ${ }^{12}-$ and the cost of obtaining the monopoly -in monetary and institutional terms (the existence of required exams or the necessity of implementation, etc.). In general, as occurs in other types of capital investments, success is determined by multiple circumstances, which does not invalidate the possibility of studying the intensity and direction of investment activity. To accomplish that, we will attempt to a) characterize and analyze the Spanish institutional environment related to industrial property to measure the degree to which it supported innovative activity; b) explain the evolution of registries throughout the $19^{\text {th }}$ century and discover the degree of foreign presence in the system; c) analyze the patents solicited by residents in Spanish territory to see whether their geographic distribution over time is related to the formation and integration of the national market; d) study the presence of firms in the system and what socio-professional activities the applicants were engaged in, which could help determine the degree of complexity of technology in Spain; e) describe how the investment processes in technologies were distributed within the economic structure of the country to discover in which sectors innovative activity was concentrated and if it coincided with what we know about the Spanish industrialization process; and finally, f) study the obligatory exploitation of patents and the duration of monopolies, to attempt to uncover data on the real effectiveness of the system in inducing innovation and the forces which brought this about.

To achieve this, the research method used has been fundamental, avoiding indirect sources and centring on original documentation -that is, on administration files and descriptive reports deposited in the Spanish Patent and Trademarks Office (OEPM)we were able to carry out a serious criticism of sources, which helped us to bring to light and understand the system's functioning. Among other things, it was fundamental in order to access various data on applicants, the transfer of rights, some lawsuits, reasons for patent expiration, renewals, fees, and above all, the approval of obligatory 
implementation of patents, which occasionally offers information on the establishment of factories, workshops and other locations designed to exploit the invention. All told, throughout the last decade we have studied approximately 48,000 files (including some Royal privileges from the 'Ancien-Regime') which cover the period 1770-1907. Such a research task would have been considered as being quite out of the question without the founding of a Convention in 1999 between the Universidad Autónoma de Madrid and the OEPM, where the task of cataloguing and research is carried out ${ }^{13}$.

\section{The institutional environment.}

As with other European absolute monarchies, throughout the Modern Age, royal privileges were granted arbitrarily to inventors and innovators of new technologies, but contrary to that of England and France ${ }^{14}$, in Spain there was never a general law regarding this point. The first documented reference to those privileges goes back to 1478, during the reign of Isabel the Catholic Monarch, with special interest regarding those granted during the $16^{\text {th }}$ and the turn of the $17^{\text {th }}$ century ${ }^{15}$. Those privileges, together with monetary rewards, government posts or assistance, continued to be the only system to motivate invention and innovation up until the $18^{\text {th }}$ century, with Spain heavily regulated both socially and economically, impeding private appropriation and market development. We would have to wait until the final disaster of the 'Ancien Regime' to witness the birth of modern regulations concerning industrial property, which, together with additional economic legislation and institutional changes, allowed the birth of capitalism, and was the direct heir of the process of liberal revolution. The first Patent Law was decreed in 1811 by the 'French' government of Joseph Bonaparte $^{16}$, after the Napoleonic invasion, and as could be expected, it was practically a copy of the French Revolution Decree of $1791^{17}$, although it barely left any mark during the War of Independence. After the brief interlude highlighted by the return of Ferdinand VII as absolute monarch, there was a renovated attempt -during the Liberal Triennial and second act of the bourgeois revolution- to organize property rights of inventions through the passing of the Decree of 2 October 1820, which, though clearly of French inspiration, was in fact domestic legislation ${ }^{18}$. Under its auspices the first few patents were granted, remaining in effect at least until 1823 (although some grants were still valid after Ferdinand's VII return to the throne) and it was substituted by the Royal Decree of 26 March $1826^{19}$. This new law introduced modifications in the text which did not alter the spirit of the previous one, becoming, with very few changes, the basis of the system for the next 50 years. The next legislature landmarks were the Law of 30 June $1878^{20}$, during the Bourbon Restoration; the Law of 16 May $1902^{21}$; the Royal Decree of 26 July $1929^{22}$, during the Primo de Rivera dictatorship; and the 11/1986 Law of 20 March, in the more recent period of democratic normalization ${ }^{23}$; all of which has expanded, complicated and adapted industrial property protection over time, although, at least until Spain's entrance in the European Union, the basic structure of the system has remained practically intact ${ }^{24}$. 
Table 1. Patent Legislation in Spain. $19^{\text {th }}$ and $20^{\text {th }}$ centuries.

\begin{tabular}{|c|c|c|c|c|c|c|c|c|}
\hline LAW & $\begin{array}{c}\text { Preliminary } \\
\text { examinations }\end{array}$ & Patents of introduction & $\begin{array}{c}\text { Maximum patents } \\
\text { duration }\end{array}$ & $\begin{array}{l}\text { Priority rights to } \\
\text { foreign patents }\end{array}$ & $\begin{array}{l}\text { Additions } \\
\text { to patents }\end{array}$ & $\begin{array}{c}\text { Implementation in } \\
\text { national territory }\end{array}$ & $\begin{array}{l}\text { Total patent fees } \\
\text { (current prices) }\end{array}$ & $\begin{array}{c}\text { Penalties to infringements } \\
\text { and jurisdiction }\end{array}$ \\
\hline 1811 & $\begin{array}{l}\text { No previous } \\
\text { technical or } \\
\text { novelty } \\
\text { examination } \\
\end{array}$ & $\begin{array}{l}\text { Yes, for } 5 \text { years (it is not } \\
\text { specified if it can or not } \\
\text { prevent importations) }\end{array}$ & 15 years & No & $\begin{array}{c}\text { Yes, but without } \\
\text { priority to the original } \\
\text { patentee }\end{array}$ & Yes, before 2 years & Unknown & $\begin{array}{l}\text { Confiscation and penalty } \\
\text { from } 18 \text { to } 36 € \text {; damages in } \\
\text { ordinary courts. }\end{array}$ \\
\hline 1820 & As in 1811 & $\begin{array}{c}\text { Yes, for } 5 \text { years without } \\
\text { ability to prevent } \\
\text { importations }\end{array}$ & 10 years & No & As in 1811 & Yes, before 2 years & $\begin{array}{c}\text { Advance payment } \\
\text { invention } 3 € ; \\
\text { introduction } 1,5 €\end{array}$ & $\begin{array}{l}\text { Penalty of } 4 \text { times the } \\
\text { estimated damage; } \\
\text { jurisdiction in ordinary } \\
\text { courts (civil) } \\
\end{array}$ \\
\hline 1826 & As in 1811 & As in 1820 & 15 years & No & No & Yes, before 1 year & $\begin{array}{c}\text { Advance payment; } \\
\text { invention } 5 \text { years } 1,5 € \\
\text { invention } 10 \text { years } 4,5 € \\
\text { invention } 15 \text { years } 9 € ; \\
\text { introduction } 4,5 € ;\end{array}$ & $\begin{array}{l}\text { Confiscation and penalty of } \\
3 \text { times the damage; } \\
\text { jurisdiction: Executive until } \\
\text { 1848, when it passed to } \\
\text { ordinary courts (civil) }\end{array}$ \\
\hline 1878 & As in 1811 & As in 1820 & 20 years & $\begin{array}{c}\text { Yes, limited to } 2 \text { years } \\
\text { but penalized until } \\
1883\end{array}$ & $\begin{array}{l}\text { Yes, with total } \\
\text { preference to original } \\
\text { patentee }\end{array}$ & Yes, before 2 years & $\begin{array}{l}\text { Annual payment; } \\
\text { first year: } 0,06 € ; \\
\text { total } 5 \text { years: } 0,9 € \\
\text { total } 10 \text { years: } 3,31 € \\
\text { total } 15 \text { years: } 7,21 € \\
\text { total } 20 \text { years: } 12,62 € \\
\end{array}$ & $\begin{array}{c}\text { Confiscation (or } \\
\text { indemnification) and } \\
\text { penalty from } 12 \text { to } 24 € \text { or } \\
\text { imprisonment; damages in } \\
\text { ordinary courts (civil o } \\
\text { criminal) } \\
\end{array}$ \\
\hline 1902 & As in 1811 & As in 1820 & 20 years & $\begin{array}{l}\text { Yes, limited to } 1 \text { year } \\
\text { according to } \\
\text { international } \\
\text { agreements } \\
\end{array}$ & As in 1878 & Yes, before 3 years & As in 1878. & As in 1878 \\
\hline 1929 & As in 1811 & $\begin{array}{l}\text { Yes, for } 10 \text { years without } \\
\text { ability to prevent } \\
\text { importations }\end{array}$ & 20 years & As in 1902 & As in 1878 & Yes, before 3 years & $\begin{array}{c}\text { Annual payment; } \\
\text { since } 1924: \\
\text { first year } 0,06 € \\
\text { total } 5 \text { years: } 1,05 € \\
\text { total } 10 \text { years: } 4,66 € \\
\text { total } 15 \text { years: } 12,47 € \\
\text { total } 20 \text { years: } 23,29 € \\
\end{array}$ & $\begin{array}{c}\text { Confiscation (or } \\
\text { indemnification), } \\
\text { imprisonment from } 6 \text { to } 24 \\
\text { months and penalty from } 6 \\
\text { to } 30 € \text {; damages in } \\
\text { ordinary courts (civil o } \\
\text { criminal) } \\
\end{array}$ \\
\hline 1986 & $\begin{array}{l}\text { Technical } \\
\text { examination and } \\
\text { novelty } \\
\text { registration }\end{array}$ & No & 20 years & As in 1902 & As in 1878 & $\begin{array}{c}\text { No. Exploitation before } 4 \\
\text { years in any country into } \\
\text { WTO }\end{array}$ & $\begin{array}{c}\text { Annual payment; } \\
\text { first } 2 \text { years: } 562,3 € \\
\text { total } 5 \text { years: } 651,83 € \\
\text { total } 10 \text { years: } 1211,46 € \\
\text { total } 15 \text { years: } 2484,70 € \\
\text { total } 20 \text { years: } 4747,09 €\end{array}$ & $\begin{array}{c}\text { Confiscation (or } \\
\text { indemnification), } \\
\text { responsibility and damages } \\
\text { in ordinary courts (civil o } \\
\text { criminal) }\end{array}$ \\
\hline
\end{tabular}

Source: SÁIZ GONZÁLEZ, J. P. (1996) 
So, for example, since 1826, any person or entity, Spanish or foreign, had the right to register patents to protect all types of mechanisms, procedures or products (although the earliest laws did not specify the latter), except, in general, scientific discoveries or marketing ideas which were not converted into practical applications, natural products and -during the entire $19^{\text {th }}$ and part of $20^{\text {th }}$ century- medications. They were never used to monopolize commercial activity (although between 1826 and 1878 they continued to be called 'privileges') and the property rights could be transferred without restrictions as with any other property. As seen in Table 1, until 1986, we must point out the absence of preliminary technical examination or novelty registration, the possibility of obtaining 'patents of introduction' without being the original inventor and without the protected object being a novelty (as long as it was unknown in Spain) and the obligation of implementing or exploiting the patent within Spanish territory in a period of 1-3 years. On the other hand, from 1878 on, the owner of the patent could make small additions without having to apply for a new one (as was the case previous to this date) and since the signing of the Paris Convention of 1883 for the protection of industrial property, previously existing foreign patents have had priority rights, within the time limits of the agreements. However, priority rights did not eliminate the possibility that with the expiration of the allotted time, anyone could apply for a patent of introduction, although never for more than five years' duration. Patents of invention, however, had a maximum time-limit of 15 years before 1878 (except that prescribed by the Law of 1820) and of 20 years after that date; being extremely costly -for the maximum time period - throughout the $19^{\text {th }}$ and the first half of the $20^{\text {th }}$ century, since it was superior to the annual wage of a qualified worker ${ }^{25}$. However, in practice, it was before 1878 when they were really expensive, since the registration fees had to be paid in advance. After that date a system of progressive annual quotas was introduced which supposed an enormous savings in protection rights, since only the first-year fees were necessary to make it effective, although the total amount paid to maintain its validity could be equal to or more than in the previous system if it was renewed during the entire allotted time.

The Spanish patent system, therefore, was based on (and was the direct heir of) the first French tradition and, in general, of follower and latecomer countries whose governments attempted to develop processes of innovation, modernization and economic growth over and above intellectual property rights. Moreover, in Spain, these characteristics dating from the $19^{\text {th }}$ century were reinforced until well into the $20^{\text {th }}$ century with a clear strategy of supporting industrial development. So, on the one hand, a system was constructed to protect national or foreign inventions, and offered fairly long grace periods, clearly defined jurisprudence and fines for frauds committed, which reinforced the strength of the patent ${ }^{26}$; but, on the other hand, as we have just explained, there were no filters applied to the granting process (beyond administrative requirements), priority rights for previously-existing patents were nonexistent or extremely limited, the introduction of technology was permitted -although with a timelimit, and without impeding the sale of the same product if it were imported-and it was obligatory to exploit the patent within national territory, all of which weakened its force. Here we see clearly an intermediate system; where, if the original inventor did not register his advances or the patent did not guarantee factory production of the protected product in Spain, anyone could easily apply for a monopoly for the same product, as long as it was implemented domestically, and therefore promoted technical innovation and diffusion. A system which, at the same time offered a certain security, left the door open to imitations and copies, which, probably, was more positive than negative for a scientifically and technologically underdeveloped country which was attempting to 
catch the last train towards industrialization. We must consider, moreover, that before 1870, we were still in a world of scarce integration of technological markets and that between 1880 and 1930, nationalist and protectionist economies were still the order of the day. It is within this context that, starting with a strong technological and scientific disadvantage, the Spanish institutional environment adopted a hybrid position, which served both to protect the investments of foreign inventors or manufacturers as well as to permit and promote national entrepreneurial projects based on foreign technological introductions. This strategy was not new and in some countries was taken to radical extremes, such as in Switzerland or Holland, were patent laws either did not exist or were abolished for most of the $19^{\text {th }}$ century while they were becoming industrialized. In Spain, an enormous problem was the constant increase in foreign technological and scientific dependency, while domestic investigation and development was declining; although it began to take place between 1920 and 1930, it was truncated by the Civil War and the Franco regime, and even today is still an unfinished task of the Spanish economy. In spite of this, and practically without its own scientific and technological development, Spain has managed to join the exclusive club of developed nations.

\section{Evolution of registries and basic characteristics of the system: strong technological dependence.}

Firstly, we must contrast, after analyzing the data on Spanish patents, the number of applications during the period studied with those of the more developed surrounding countries. Both in absolute terms and in patents per capita, Spain falls well below the European average so, for example, the mean of annual registration between 1826 and 1907 was 6.5\% of those in England during the same period, 9.7\% of France's, 9.5\% of those in Germany and 3.6\% of the U.S. average. If these same calculations are made only for patents per capita, the results vary slightly but continue to indicate the existence of an enormous gap: Spain represents barely 12\%, compared to England or the U.S., $20 \%$ of that of France, and $28 \%$ of Germany's percentage ${ }^{27}$. In absolute figures, Spanish patent series were also bested throughout the period by Austria-Hungary, Belgium, Italy and Canada, with levels similar to much smaller and less-densely populated countries (such as Holland ${ }^{28}$, Sweden or Denmark) and only superior to Norway, Finland, Russia or Portugal. In per capita patents, Spain bested the last three countries, not far from Italy or even Austria before 1890, but separated from all other countries by a very wide gap. 
Graphic 1. National and foreign patent applications. Spain 1820-1907.



Source: Gaceta de Madrid for privileges from 1820 to 1826. Between 1826 and 1907: Original documents of patents at the Oficina Española de Patentes y Marcas (OEPM).

Aside from the numerical distance with respect to other countries, which reveals the narrowness of the Spanish market and the relative underdevelopment of processes of technological innovation, it is interesting to observe the annual registration over time. At the end of the 'Ancien Regime', many more awards (cash, government posts, development aid, and so on) than privileges were applied for; we could hardly find 50 privileges between 1770 and 1800 and between 1816 and 1820. This is only a sample, since there are no centralized archives, but we believe it is significant in order to study the protection difficulties encountered by the few entrepreneurs and innovators of the period. It was after the institutional changes induced by the liberal patent legislation of 1820 and the Decree of 1826 that the system began to possess continuity. However, as can be seen in Graph 1, at the beginning there were still very few patents granted due to the political and social instability of the country, while the middle-class revolution and the Carlist insurrections were still ahead. The first important impulse in patent applications took place between 1845 and 1864, two more stable and politically moderate decades (except the 'Bienio Progresista' between 1854 and 1856 in which the foundations for railways and banking were established) and in an early economic growth symbolized by the construction of a railway system and the expansion of industrial activity. The financial crisis of 1864 and the revolutionary events of 1868, which led to Queen Isabel II's exile, once again upset the Spanish political and economic balance during the following years, which had an immediate repercussion on the number of patents solicited. This indicates what a critical moment it was, in which the cantonalist and Carlist rebellions, the changing provisional governments and the establishment of the First Republic had very negative economic consequences, which were not overcome until Alphonse XII's restoration in 1874-75. From that moment on, and until the end of the period studied, stability reigned, launching the 'peaceful pendulum' of the conservative and liberal parties alternating in power and the consolidation of the capitalist system in Spain. Legal reforms followed, including the Patent Law of 1878, and the economic situation improved, progressively increasing 
agricultural productivity and mining activity and consolidating industrial areas: Catalonia, The Basque Country, Madrid and Valencia. Due to the preceding and, likely, to lower patent fees, there was a sudden and continuous increase in applications throughout the following decades.

Graph 1 also analyses the different patenting behaviour of nationals and foreigners. As seen, before 1845 the system was used more by Spaniards, because the political instability already described and the lack of economic possibilities did not facilitate foreign investment. However, between 1845 and 1878, the number of national and foreign patents evened out, which probably indicated an improvement in legal guarantees and the industrial situation which attracted the first European investors towards basic sectors such as railways or mining. This tendency was accentuated by the legal reform of 1878, which provoked an immediate increase in the percentage of foreign patents over national ones. Undoubtedly the offer of priority rights, the possibility of making additions, and, above all, the cheapening of registration fees greatly influenced the influx of foreign inventors and entrepreneurs. Hence, as seen in Table 1, the requirement to satisfy the fees at once at the moment of registration made, before 1878, the procurement of a patent 150 times more costly than the same action after that year ${ }^{29}$. At any rate, after the institutional changes, the continuing increase in foreign patents must be explained by other factors, such as the increase in business possibilities in the Spanish economy (which, without a doubt, national applicants were also responding to) and, largely, by the tremendous technological expansion by developing countries during the second industrial revolution, which increased the supply of new products and new ways of doing things. It was the moment of the proliferation of corporate patents, international agreements on industrial property and a progressive integration of technological markets which provoked an ever-greater profusion of multiple patents which guaranteed wider geographical protection.

Table 2. Patent types and applicants' nationality. Spain 1770-1907.

\begin{tabular}{ccccccc}
\hline & $\begin{array}{c}\text { Spanish } \\
\text { patents of } \\
\text { invention } \\
(\boldsymbol{a})\end{array}$ & $\begin{array}{c}\text { Spanish } \\
\text { patents of } \\
\text { introduction } \\
(\boldsymbol{b})\end{array}$ & $\begin{array}{c}\text { Foreign } \\
\text { patents of } \\
\text { invention } \\
(\boldsymbol{c})\end{array}$ & $\begin{array}{c}\text { Foreign } \\
\text { patents of } \\
\text { introduction } \\
(\boldsymbol{d})\end{array}$ & $\begin{array}{c}\text { Presence of } \\
\text { foreign } \\
\text { technology } \\
(\boldsymbol{b}+\boldsymbol{c}+\boldsymbol{d})\end{array}$ & PATENTS \\
\hline $1770-1826$ & 55,7 & $\%$ & $\%$ & $\%$ & $\mathbf{\%}$ & \\
$1826-1850$ & 35,1 & 19,0 & 19,0 & 6,3 & $\mathbf{4 4 , 3}$ & 79 \\
$1851-1878$ & 35,8 & 28,9 & 17,3 & 18,8 & $\mathbf{6 4 , 9}$ & 890 \\
$1878-1907$ & 32,3 & 9,9 & 46,7 & 7,5 & $\mathbf{6 4 , 2}$ & 4244 \\
\hline
\end{tabular}

Source: Archivo Histórico Nacional (AHN, Sección Fomento) and Gaceta de Madrid for privileges from 1770 to 1826. Between 1826 and 1907: Original documents of patents at the OEPM.

The widespread participation of foreign inventors and entrepreneurs in the patent system was one of the basic characteristics of the Spanish model, in which there was an even greater foreign technological presence than the statistics indicate. As seen in Table 2, if we add the number of patents applied for by foreigners to the number of Spanish patents of introduction (which are necessarily based on foreign technological developments) the result is that more than $67 \%$ of the patents registered from the end of the $18^{\text {th }}$ Century to 1907 are based on foreign inventions. Upon breaking down these data into periods, we see that in the sample of 79 privileges and patents granted between 
1770 and 1826, the degree of foreign technological presence $(b+c+d)$ is almost $45 \%$, although Spanish applicants predominate. It is not surprising that there was a lesser participation of foreign citizens during a period of international conflict and with Spain experiencing a social, economic, political, military and colonial crisis. In general, as shown, during the first half of the $19^{\text {th }}$ century, the use of the Spanish patent system by foreigners was lesser than in the second half; however, due to the proliferation of Spaniards who used the introduction patent, we can see that from 1826 on, foreign technological presence increased, stabilizing at 65\%. Between 1826 and 1850 there were also many foreign introduction patents, mainly French (many of them Spanish residents), which were used to protect third-party technologies, taking advantage of business opportunities in the Spanish market. But in the remainder of the period studied (1851-1907) the percentage of patents of introduction compared to patents of invention decreased drastically, both among Spaniards and foreigners, while at the same time foreign invention patents increased, more than likely because, increasingly, the inventors and entrepreneurs who had originally developed the innovations registered them simultaneously in several countries if there was any expectation of profit. This tendency increased between 1878 and 1907, in which foreign technological presence rose to $68 \%$, due, basically, to patents of invention solicited from abroad, to which we must add the $8 \%$ of introduction patents solicited by Spanish nationals. Therefore, the patent system and, in general, the Spanish technological system manifested, throughout the period, a clear dependence on foreign scientific and technological advances, which continued to increase over time.

Finally, we must point out that when the nationalities of the applicants of Spanish patents are studied, we discover a predominance of French manufacturers and entrepreneurs, followed by British, German and American applicants. Before 1878 this tendency was overwhelming, with France making up a total of $31 \%$ of all patents, which demonstrates the French interest in investing in new technologies in the Spanish market place. The British followed with more than 9\%, Americans with 2.2\% and Germans with $1.6 \%^{30}$. However, in the final quarter of the $19^{\text {th }}$ century this tendency changed: the participation of France dropped to 17\%, that of England stabilized at around $10 \%$, and Germany and the U.S. increased to over $10 \%$ each, corroborating the international competition of these two economies, during their technological and industrial expansion ${ }^{31}$. Generally, this distribution of nationalities with respect to foreign patents coincides perfectly with studies on foreign capital investments in Spain during the same period, which strongly suggests that patents can be used as valid indicators of invest in new technologies ${ }^{32}$.

\section{Applicants' residence and regional distribution of patents.}

Another interesting aspect of the Spanish patent system which deserves analysis is the applicants' place of residence, vital to the understanding of geographical distribution of innovative activity in Spain and of the foreign inventors' and entrepreneurs' contact with the real economy of the country. As seen in Table 3, between 1770 and 1878 residents in Spain at the moment of application predominated (although this percentage diminished gradually throughout the period), while between 1878 and 1907 the situation was reversed; foreign non-residents out-numbered Spanish residents. In any case, these figures indicate that, during the period analyzed, a sizable portion of foreigners who applied for protection did it while living in Spain: more than half of all foreign applicants before 1850, practically one-fourth between 1851 and 1878, and somewhat less than 4\% between 1878 and 1907 (from the relationship between columns $b$ and c of Table 3 ). Therefore, it seems very clear that before the 
Restoration -during the beginning of the economic modernization process in Spain- a large part of the transfer of foreign technological information was produced through the immigration of qualified labour, which we know was vital to the development of many sectors such as railways, mining or basic metals; however, during the last quarter or the $19^{\text {th }}$ century and the first few years of the $20^{\text {th }}$ century a radical change took place, caused by the massive arrival of foreign applications 'from abroad', which once again indicates the institutional changes brought about by the Law of 1878, the acceleration of innovations during the second industrial revolution and the process of the internationalization of the patent systems as the origin of the later tendencies of patent registration in the Spanish market. Undoubtedly, within any period, most foreign residents in Spain who used the industrial property system had a direct interest in the productive activity of the country. Among these, French technicians and entrepreneurs stand out, followed by British, German, Italian, Belgian and Swiss citizens ${ }^{33}$, which not only falls in with historical knowledge of foreign firms and investments in Spain during the $19^{\text {th }}$ century, but will also require, in the future, that researchers pay special attention to the role played by the mobility of European capital and labour in the process of Spanish industrialization.

Table 3. Patent applicants' residence. Spain 1770-1907

\begin{tabular}{cccccc}
\hline & $\begin{array}{c}\text { Spanish Residents } \\
(\boldsymbol{a})\end{array}$ & $\begin{array}{c}\text { Foreign Residents } \\
(\boldsymbol{b})\end{array}$ & $\begin{array}{c}\text { TOTAL Residents } \\
(\boldsymbol{a}+\boldsymbol{b})\end{array}$ & $\begin{array}{c}\text { Non-Residents } \\
(\boldsymbol{c})\end{array}$ & Patents \\
\hline & $\%$ & $\%$ & $\%$ & $\%$ & \\
$1770-1826$ & 80,8 & 11,0 & 91,8 & 8,2 & $73^{*}$ \\
$1826-1850$ & 63,4 & 20,9 & 84,3 & 15,7 & $875^{*}$ \\
$1851-1878$ & 45,5 & 14,5 & 59,9 & 40,1 & $4231^{*}$ \\
$1878-1907$ & 40,2 & 2,3 & 42,4 & 57,6 & $41711^{*}$ \\
\hline
\end{tabular}

* Calculations were made based on $98,7 \%$ of patents. The remainder gave no place of residence.

Source: See Table 2.

Once we separate patents solicited from abroad from those solicited by either foreign or Spanish residents, we can distribute these last two according to geographical locations within Spain for the periods studied, to attempt to clarify some of the questions we raised at the beginning of this work. If, as we have suggested, patents are a valid indicator of investment in new technologies, the increase in their use in national territory would depend, as with any other investment activity, on two fundamental questions: a) the existence of reasonable expectation of profit, which would, directly or indirectly, be a function of the degree of market development and integration and population and income growth and b) the availability of previously accumulated capital. Before 1850 neither or these two factors were present in Spain. There barely had been an initial process of economic modernization focussed on the Catalonian cotton sector, some mining and basic metals activity in Andalusia and the Basque Country, and geographically disperse production of basic consumer goods, with some concentration in urban markets such as Madrid and some areas of the East Coast. The railway system had not yet been laid down, ordinary roads were very poor, there were no canals or rivers to be navigated, and the most efficient means of transport was by coastal trading, which made for a fragmented and scarcely integrated national market. Moreover, the basis of construction and expansion of the Spanish financial system was not yet in place and difficulties in obtaining credit and capital was a serious problem. 
Figure 1. Regional distribution of resident patents. Spain 1770-1907. One point per patent*.
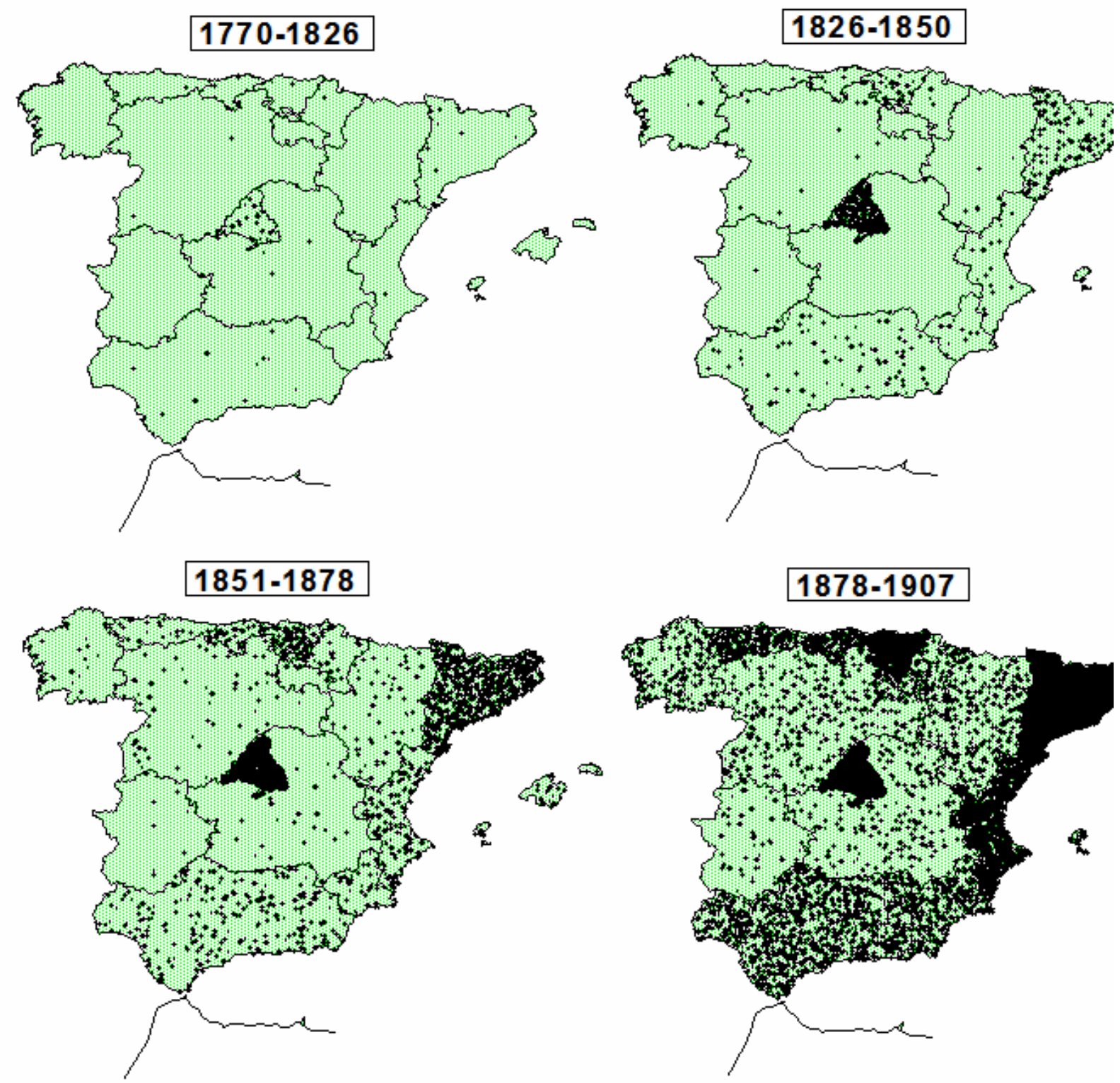

* Patents registered by residents in American colonies, Ceuta, Melilla and the Canary Isles are not counted.

Source: See Table 2.

In the context just described, the scarcity of patents was general during the first half of the $19^{\text {th }}$ century, although the ones solicited, as seen in the first two maps in Figure 1, tended to be grouped around Madrid and major ports, especially in Catalonia and Andalucia, but also in Valencia and some northern ports. That is, those zones with some possibility of communication, in which the market was slowly becoming integrated, which brought together the first modern industries and had begun to accumulate mercantile capital in previous periods. Such traditional zones as Barcelona, Bilbao, Valencia and southern cities such as Cadiz and Seville (with its important role in American commerce in previous centuries) were the places of residence of many of 
those who patented new technologies. Madrid was the court, the administrative centre and the headquarters of industrial property management, which undoubtedly influenced its place as the region with a greater number of patents, but we must not forget that it was also the starting point of a radial system of roads, an important market of goods and services, and a centre of financial and bourse activity, with a constant flow of capital.

The maps in Figure 1, corresponding to the second half of the $19^{\text {th }}$ century and the first few years of the $20^{\text {th }}$ century, demonstrate the process of progressive concentration of patents in Catalonia, Madrid (constantly losing relative weight), the Basque Country, Valencia, Cantabria, Asturias, Murcia and Andalucia, that is, in the better-connected regions, with greater access to capital, with a constant increase in industrialization and the highest concentration of population, which is a faithful reflection of market integration. Between 1855 and 1870 the basic structure of the railway system was established following the radial structure of the ordinary roads which joined Madrid to the major ports, this process being finished by the turn of the century $^{34}$; also, during the same period, especially after 1876, port infrastructures were improved and expanded, and the merchant fleet was renewed ${ }^{35}$; moreover, after 1855 , Spanish mixed banking, and the expansion of financial intermediary groups commercial banks and industrial credit unions- which operated in Madrid and the main coastal cities $^{36}$ was established. It is not surprising, therefore, that the bulk of patents continued to be solicited in the same regions; that is, in the areas where the process of market development and modern economic expansion had begun -and was maturingand where large-scale manufacturing and financial economies were developing, which influenced the later founding of major industries and the attraction of greater population and capital. Obviously, the general improvement in transport and industrial activity also generated patent applications from inland areas such as Castille and Aragon, which previously were largely unrepresented, increasing especially in the northern half of the peninsula during the Restoration. But, in any case, the density of the railway and banking networks was deficient outside the main spokes which led from the central hub to the port cities; so, except in Madrid -crossroads for all railway lines, and also a city of industrial development at the end of the $19^{\text {th }}$ century, and, above all, of construction and service activities-, inland, agriculture and processing of raw materials predominated, with little innovation. All this coincides with K. Sokoloff's original theory of the influence of market development and the proximity of communication lines on inventive and innovative expansion in the U.S. ${ }^{37}$, which seems, also, to be applicable to Spain's case.

\section{Legal status and socio-professional activity of applicants.}

Research into applicants' legal and professional situation may be necessary in order to understand the functioning of the patent system in Spain. For example, in all the periods studied, technologies were largely registered by individual patentees instead of by two or more inventors or corporate applicants. However, this tendency decreased over time, since at the end of the $18^{\text {th }}$ century $90 \%$ of patents belonged to individuals, between 1826 and 1878 this figure dropped to 79\%, and between 1878 and 1907 to $72 \%$, while collective and company applications increased slightly. We mention shared patents because, although legally they do not come from a society, we have discovered that sometimes they are related to firms or corporations which prefer patents to be registered with the names of individuals or partners (avoiding, for example, embargo in case of bankruptcy); or, in other cases, we find that this is a preliminary step in forming a company which will later receive the patent. At any rate, collective registrations indicate some type of previous collaboration or association between inventors or 
manufacturers -although not strictly mercantile- which suggest the necessity of separating them from individual patents and bringing them closer to the corporate world.

Table 4. Legal Status of patent applicants. Spain 1770-1907.

\begin{tabular}{|c|c|c|c|c|}
\hline & \multicolumn{4}{|c|}{ SPANIARDS } \\
\hline & $\begin{array}{c}\text { One } \\
\text { individual } \\
\text { (a) } \\
\%\end{array}$ & $\begin{array}{c}\text { Two or more } \\
\text { individuals } \\
\text { (b) } \\
\%\end{array}$ & $\begin{array}{c}\text { Corporations } \\
\text { (c) } \\
\%\end{array}$ & Patents \\
\hline $1770-1826$ & 88,1 & 6,8 & 5,1 & 59 \\
\hline $1826-1850$ & 76,6 & 11,2 & 12,1 & 569 \\
\hline $1851-1878$ & 80,4 & 9,8 & 9,7 & 1942 \\
\hline \multirow[t]{3}{*}{ 1878-1907 } & 78,3 & 7,6 & 14,2 & 17115 \\
\hline & \multicolumn{4}{|c|}{ FOREIGNERS } \\
\hline & $\begin{array}{c}\text { One } \\
\text { individual } \\
\text { (a) } \\
\%\end{array}$ & $\begin{array}{c}\text { Two or more } \\
\text { individuals } \\
\text { (b) } \\
\%\end{array}$ & $\begin{array}{c}\text { Corporations } \\
\text { (c) } \\
\%\end{array}$ & Patents \\
\hline $1770-1826$ & 95,0 & 5,0 & -- & 20 \\
\hline $1826-1850$ & 84,1 & 12,1 & 3,7 & 321 \\
\hline $1851-1878$ & 79,0 & 13,6 & 7,4 & 2302 \\
\hline 1878-1907 & 68,0 & 13,0 & 18,9 & 25197 \\
\hline
\end{tabular}

Source: See Table 2.

As seen in Table 4, if patents are broken down by the applicant's nationality in order to analyze his legal status, with minor differences, Spanish and foreign patentees' behaviour was basically the same. Before 1850, the predominance of individuals was total in both groups (even greater among foreign inventors), percentages were similar in shared patents, and corporate applications, especially foreign, were rare ${ }^{38}$. The situation remained the same half-way through the $19^{\text {th }}$ century, with $80 \%$ of individual applications in both groups and collective and corporate patents not far behind. However, between 1878 and 1907 certain changes came about as a result of the increase of non-resident records. Among Spanish nationals, the individual patent predominated at $78.3 \%$, while corporate patents increased to $14 \%$; but among foreigners this tendency was more pronounced, with individual patents dropping to $68 \%$, and collective (13\%) and corporate patents (19\%) increasing, clearly reflecting the greater role of companies in technological activities in developed countries. But, in general, the legal status of applicants shows a patent system mainly used by individuals, especially in the first three-fourths of the $19^{\text {th }}$ century, and up until the $20^{\text {th }}$ century with Spanish applicants. The predominance of individual patents was general in the rest of Europe and the U.S. at least until 1850, but in Spain this situation was prolonged, due to the technical level of the country, economic lag and scarcity of qualified workers, which made viable the development and implementation of simple technologies, easy to exploit, already tested abroad and which did not require large investments. Many of these inventions or introductions were the result of personal research and of modifications of existing technology, in small workshops, based on practical experience and direct contact with production processes; a phenomenon which changed in Europe from 1870 on. In the last quarter of the $19^{\text {th }}$ century, during the transition to the new manufacturing paradigm of the second industrial revolution, both the complexity of technological systems and the 
necessity of investment in research and development were progressively increased, which required concentrations of capital only available through societies and firms.

This panorama becomes clear if we look at other socio-economic and professional factors pertaining to individual patent applicants, information not always clearly expressed, but which we were able to reconstruct in many cases thanks to direct work with the patent documents. Concretely, we obtained valuable data on the social and professional conditions of over half of the individual applicants for privileges previous to 1826, for $64 \%$ from that date until 1850, 76\% between 1851 and 1878, and just 25\% for individual patents registered between 1878 and 1907, which gives us a sample of 12,330 inventions. We must not lose sight of the fact that the patentee himself mentions his profession or social affiliation whenever he filled out applications, which in some cases were not explicit enough (such as 'owner', 'capitalist' or 'trader') but after careful study of the more obscure terms ${ }^{39}$, we are able to offer a classification into four major groups according to the economic activity of the applicant: a) civil servants, which includes low-level clerks, high-level appointments, lawyers, military officers, university professors or technicians working in an administrative position; b) liberal professionals and qualified technicians, such as lawyers, (many) engineers, architects, doctors, pharmacists, physicists, chemists, notaries, directors, designers, professors, etc., self-employed or not, always emphasizing their academic title; c) entrepreneurs, manufacturers, businessmen, master craftsmen, craftsmen and salesmen; and d) others; that is, a heterogeneous group including unskilled and semi-qualified labourers, nobility, students, housewives, etc.

Table 5. Socio-professional situation of individual patent applicants. Spain 17701907.

\begin{tabular}{|c|c|c|c|c|c|}
\hline & \multicolumn{5}{|c|}{ SPANIARDS } \\
\hline & $\begin{array}{l}\text { Civil servants } \\
\qquad \begin{array}{c}\text { (a) } \\
\%\end{array}\end{array}$ & $\begin{array}{c}\text { Liberal professionals, } \\
\text { qualified technicians } \\
\text { (b) } \\
\%\end{array}$ & $\begin{array}{c}\text { Manufacturers, salesmen, } \\
\text { craftsmen... } \\
(c) \\
\%\end{array}$ & $\begin{array}{l}\text { Others } \\
\text { (d) } \\
\%\end{array}$ & Patents \\
\hline $1770-1826$ & 17,6 & 17,6 & 58,8 & 5,9 & $34 *$ \\
\hline $1826-1850$ & 15,7 & 15,4 & 66,9 & 2,1 & $332 *$ \\
\hline $1851-1878$ & 10,1 & 17,9 & 69,8 & 2,3 & $1528 *$ \\
\hline \multirow[t]{3}{*}{ 1878-1907 } & 11,9 & 27,3 & 54,6 & 6,2 & 5145* \\
\hline & \multicolumn{5}{|c|}{ FOREIGNERS } \\
\hline & $\begin{array}{l}\text { Civil servants } \\
\qquad \begin{array}{l}\text { (a) } \\
\%\end{array}\end{array}$ & $\begin{array}{c}\text { Liberal professionals, } \\
\text { qualified technicians } \\
\text { (b) } \\
\%\end{array}$ & $\begin{array}{c}\text { Manufacturers, salesmen, } \\
\text { craftsmen... } \\
(c) \\
\%\end{array}$ & $\begin{array}{l}\text { Others } \\
\text { (d) } \\
\%\end{array}$ & Patents \\
\hline $1770-1826$ & 16,7 & 16,7 & 66,7 & -- & $6 *$ \\
\hline $1826-1850$ & 9,2 & 37,0 & 51,6 & 2,2 & $184^{*}$ \\
\hline $1851-1878$ & 5,1 & 45,8 & 47,3 & 1,8 & $1420 *$ \\
\hline 1878-1907 & 6,7 & 62,2 & 25,5 & 5,6 & $3681 *$ \\
\hline
\end{tabular}

* Calculations were made based on an average of $31 \%$ of individual patents between 1770 and 1907 . The rest indicated no profession. We have expressly excluded corporate patents ${ }^{40}$.

Source: See Table 2. 
In general, if we join the results of all the periods studied, the group made up of manufacturers, businessmen, salesmen, craftsmen, etc. is the largest (with almost 50\% of all applications), followed by liberal professions and technicians (38,5\%) and administrators (just over 9\%), which indicates that the patent system was used primarily by those directly related to production processes, over and above skilled workers. But when we cross these data with those of the applicants' nationality, we see in Table 5 that percentages of the different socio-professional groups vary according to whether they were nationals or foreigners. Aside from the privileges extended before 1826, where the figures are similar regardless of nationality, some interesting differences can be noted during the remaining periods. Among national applicants, group c) predominates with between 54 and $69 \%$ of registrations by all sorts of craftsmen, small manufacturers, salesmen and businessmen, even after 1878. However, there were very few qualified technicians represented before 1878 (between 15 and 18\% of patents) and among them engineers, who hardly appeared before 1850, although their presence increased from 1851 to 1907 (especially after 1878), becoming the most populous category in group b). In any case, compared to the group of manufacturers, etc., Spanish technicians were always in the minority -although from 1878 to 1907 their presence increased to 27\%- which is perfectly understandable in light of the tardiness of specialized training centres (the first industrial engineering schools, for example, were not founded until the second half of the century). With respect to administrators, their presence was also minor, especially after 1850; applicants with scientific or technical qualifications (engineers, university professors, etc.) were also scarce; and with respect to other groups, the presence of wage earners was also very low throughout the periods studied. We return, therefore, to the idea that the national innovation process was backed by small workshops and factories, with simple techniques, modifying or introducing foreign technology, with technical skills based on practical experience more than technical training -learning by doing and learning by using ${ }^{41}-$, which leads us to insist on the idea of gradual, rather than radical, technological advances, demand-driven by production processes themselves.

The use of the patent system by craftsmen, master craftsmen and small manufacturers without scientific qualification but with technical and practical training also occurred in pioneering countries such as the U. K., where this type of applicant was common before 1850; however, unlike in Spain, the presence of engineers continued to increase from 1830 on, and above all, in the second half of the 19th century, when, together with companies, they took over inventive and innovative activity ${ }^{42}$. Some of this can be seen among the foreigners who patented in Spain, as seen in Table 5, since producers, businessmen, etc. made up the majority of patent seekers before 1850, but engineers and skilled technicians became the most important group after 1878, while administrators and other professionals were scarce. Between 1826 and 1878, the proportion of workers with scientific training was between 37 and $46 \%$ of foreign applicants (always more than that of nationals), most of them being engineers, which reveals the technical quality and complexity of the inventions registered, above that of nationals; however, during the same period, among the members of group c), we find that small businessmen, craftsmen, master craftsmen and salesmen predominate (47$51 \%$ ), insisting on the role of the practical training of this group in the transfer of technology in the early stages of European industrialization. Between 1878 and 1907 this model clearly changed; although the presence of professionals from group c) with Spanish patents was still significant (25,5\%), it decreased in proportion to the gains made by qualified workers (especially engineers), which grew to 62.2\%. Hence, craftsmen and small manufacturers were no longer predominant, being replaced by 
technicians and scientists, not only asking for patents themselves, but also working in the implementation departments of large manufacturing and business corporations, who appropriated the results and were the owners of the patents. Once again we see here the innovation model of the second industrial revolution.

\section{Patents and structure of the Spanish economy.}

One of the problems with using patent series is their sectorial classification in order to trace the distribution of inventive and innovative activity within a specific economy. The usual approach, originated by J. Schmookler, consists of grouping the inventions according to the sector in which the new technology makes its impact; that is, where productivity would tend to increase with the implementation of that invention ${ }^{43}$. However, as Schmookler himself immediately realized, and other authors have continued to point out ${ }^{44}$, the fundamental problem is the inability to classify certain inventions, since they impact several industries or sectors; for example, advances in the steam engine. In spite of these problems, we have decided to classify the Spanish patents using the same system, but combining it with the technical criteria used in the International Patent Classification ${ }^{45}$, since Spanish documents have not been officially classified for dates previous to 1968. On the one hand, we have had the advantage of working directly with the descriptions and plans of the inventions, and, on the other, the disadvantage of having lesser technical knowledge than engineers specialized in classifying patents. However, before 1880, registered technologies were sufficiently available and simple enough to guarantee a high level of quality in this classification, and although after that date the technologies became more complicated, a general approach towards large technical and industrial groups, without the minute detail pursued by those examiners, has facilitated our work ${ }^{46}$. We have consistently attempted to assign each registered technology to the sector most likely to use it, but when it becomes clear that it has a multisectorial application, we have classified it in the generic group of machinery and equipment. That is, if a patent supposes an advance in a steam engine adapted to navigation or railways, we classify it in those sectors, but if it is a general improvement valid for any and all implementations, we include it in machinery and equipment, independently of the fact that all these inventions belong to the same technological section of the international classification WIPO. We are well aware that it is not a perfect procedure but also that, by using it, we can, at least, make our first observations on the sectorial structure of investment in new technologies in Spain.

Table 6. Distribution of patent applications according to economic activities. Spain 1770-1907.

\begin{tabular}{lccccc}
\hline Sectors & $\mathbf{1 7 7 0 - 1 8 2 6}$ & $\mathbf{1 8 2 6 - 1 8 5 0}$ & $\mathbf{1 8 5 1 - 1 8 7 8}$ & $\mathbf{1 8 7 8 - 1 9 0 7}$ & $\mathbf{1 7 7 0 - 1 9 0 7}$ \\
\hline & $\%$ & $\%$ & $\%$ & $\%$ & $\mathbf{\%}$ \\
Machinery and equipment & 15,2 & 10,9 & 13,4 & 19,2 & $\mathbf{1 8 , 5}$ \\
Services & 7,6 & 7,1 & 9,4 & 13,4 & $\mathbf{1 2 , 9}$ \\
Textile & 10,1 & 14,5 & 12,7 & 12,0 & $\mathbf{1 2 , 1}$ \\
Food, beverages and tobacco & 21,5 & 15,4 & 11,6 & 9,9 & $\mathbf{1 0 , 2}$ \\
Chemical & 19,0 & 11,1 & 8,5 & 6,8 & $\mathbf{7 , 1}$ \\
Basic metals & 3,8 & 11,9 & 8,2 & 5,0 & $\mathbf{5 , 4}$ \\
Electricity & -- & 0,1 & 0,5 & 5,2 & $\mathbf{4 , 7}$ \\
Construction & -- & 6,0 & 5,4 & 3,8 & $\mathbf{4 , 0}$ \\
Paper and graphic arts & 3,8 & 4,5 & 4,1 & 3,9 & $\mathbf{4 , 0}$ \\
Railway & -- & 1,6 & 4,9 & 3,6 & $\mathbf{3 , 7}$ \\
\hline
\end{tabular}




\begin{tabular}{lccccc}
\hline Arms industry & -- & 0,5 & 3,7 & 3,7 & $\mathbf{3 , 6}$ \\
Gas and lighting & -- & 2,6 & 4,2 & 3,1 & $\mathbf{3 , 2}$ \\
Non-rail transport & 2,5 & 2,1 & 1,9 & 2,8 & $\mathbf{2 , 7}$ \\
Agriculture and cattle farming & 6,3 & 1,1 & 1,6 & 2,0 & $\mathbf{1 , 9}$ \\
Sea transports and ports & 3,8 & 3,5 & 2,3 & 1,8 & $\mathbf{1 , 9}$ \\
Mining and coal & 1,3 & 4,2 & 4,2 & 1,3 & $\mathbf{1 , 6}$ \\
Lumber industry & 5,1 & 2,5 & 1,8 & 1,1 & $\mathbf{1 , 2}$ \\
Communications & -- & 0,3 & 1,2 & 1,1 & $\mathbf{1 , 1}$ \\
Aeronautics & -- & 0,0 & 0,3 & 0,2 & $\mathbf{0 , 2}$ \\
TOTAL PATENTS & 79 & $888^{*}$ & $4229 *$ & $42103^{*}$ & $\mathbf{4 7 2 9 9}$ \\
\hline
\end{tabular}

*The calculations are based on $99.5 \%$ of the patents studied. The remainder was unclassifiable.

Source: See Table 2.

As seen in Table 6, throughout the period studied, more than $80 \%$ of the patents are concentrated in ten activity sectors, which, with few exceptions and changes in order, are basically the same. During the 19th century, therefore, a common pattern of investment in new technology is maintained, beyond obvious alterations due to the nature of technique itself or to the process of economic growth. So, the objects patented pointed to leading sectors -technologically speaking-, which caused no surprise during a modernization process, even in such an underdeveloped country as Spain. That is the case of the textile industry, with an average of $12 \%$ of related inventions, situated from the beginning of the 19th century firmly in the top two or three positions; the basic metals industry with $5.4 \%$ but even greater before 1878 ; or even the machinery and mechanical construction industries, evidently linked to the latter and progressively increasing in participation, especially during the second industrial revolution, becoming the most important (18\%). However, it is significant that many patents refer to activities which, theoretically, are not normally considered innovative during the early stages of industrialization, such as advances in the services sector ${ }^{47}$, whose presence increased constantly to make up almost $13 \%$ of all patents; innovations in the food, beverage and tobacco industries ${ }^{48}$, which while losing points throughout the century, stabilized at $10,2 \%$; discoveries related to chemical production ${ }^{49}$, which descended slowly to an average of $7,1 \%$; or even patents connected to the construction sector ${ }^{50}$ or the paper and graphic arts industry, with $4 \%$ each.

We know that the cotton textile industry, basically Catalonian, began its expansion and mechanization very early, rapidly organizing factory production and becoming the most innovative and advanced industry in the country ${ }^{51}$. It is also well known that the basic metals industry went through its first modernization period before 1850 in Andalusia, and after this date, in the North, especially in the Basque Country with a strong specialization in the sector after $1881^{52}$. The development of the machinery and equipment industry was much slower during the first three-fourths of the 19th century and was linked to the existence of repair shops for relatively simple machinery (such as water pumps, primary motors, steam engines, boilers, furnaces, transmissions, turbines, basic machine-tools, etc.) and located around large cities such as Madrid, Barcelona, Bilbao, Valencia, Zaragoza..., where between 1880 and 1930 several large factories and companies were founded ${ }^{53}$. However, the food, construction, basic services and chemical (before 1875) sectors were more dispersed across the Spanish geography -although always connected to Madrid and the principal port citieswith smaller production units -often somewhere between mass-produced and handcrafted- and with uncomplicated techniques. In spite of this, and less well known 
to historians, they weighed heavily in Spanish economic growth ${ }^{54}$. This phenomenon is not exclusive to undeveloped countries, since, for example in the U.K., between 1711 and 1850, some researchers have found patented inventive activity not normally associated with technological change ${ }^{55}$, although in the case of latecomers, this industrialization or protoindustrialization spread across non-leading sectors could be much more important for their model of growth and modernization than it was in pioneering nations.

Finally, we would like to point out that inventive activity in other areas was especially relevant in specific periods, such as the $5 \%$ of railway patents between 1851 and 1878 demonstrates, coinciding with the laying down of the tracks; or the 4,2\% corresponding to mining, coal and the gas industries in the moment of greater activity in these sectors. It is probable that some sectors, in which technology could be a fundamental factor, such as railways and mining, were under-represented in the patent system, which could be explained by the especial conditions surrounding its expansion since, in both cases, governmental permission was necessary in order to implement the exploitation, they required large capital investments (mostly foreign) and were totally dependent on foreign innovation. In this context of limiting any competition, it is not surprising that much machinery was imported directly without being registered in Spain $^{56}$. Moreover, patents in the electric industry were significant during the last quarter of the 19th century (5,2\%), coinciding with the growth of the new energy sector during the second European industrial revolution, in which, in general, new technological trajectories were established in many industries and sectors, such as the manufacture of machinery and equipment, where ever more complex machine-tools were being produced; in the birth of the great chemical industry, with certain important factories founded in Spain such as the production of explosives, caustic soda, etc ${ }^{57}$; in activities tied to the services sector with new industrial branches, such as photography; in highway transport, with the development of the internal combustion engine; or in the arms industry with successive inventions which in turn opened up new paths of technological development. On the other hand, patents related to agriculture, fishing, cattle farming, lumber, communications, navigation and transport systems in general, have always been scarce.

Table 7. Percentages of foreign technology (foreign patents plus Spanish introduction patents) in different economic sectors. Spain, 1770-1907.

\begin{tabular}{lcccc}
\hline Sectors & $\begin{array}{c}\mathbf{1 7 7 0 - 1 8 7 8} \\
(\mathbf{a})\end{array}$ & $\begin{array}{c}\mathbf{1 8 7 8 - 1 9 0 7} \\
(\mathbf{b})\end{array}$ & $\begin{array}{c}\mathbf{1 7 7 0 - 1 9 0 7} \\
(\boldsymbol{c})\end{array}$ & $(\boldsymbol{b}-\boldsymbol{a})$ \\
\hline & $\%$ & $\%$ & $\mathbf{9}$ & $\%$ \\
Communications & 74,5 & 83,8 & $\mathbf{8 2 , 8}$ & 9,3 \\
Basic metals & 74,1 & 83,9 & $\mathbf{8 2 , 2}$ & 9,8 \\
Arms industry & 68,8 & 81,9 & $\mathbf{8 0 , 7}$ & 13,1 \\
Electricity & 100,0 & 78,2 & $\mathbf{7 8 , 4}$ & $-21,8$ \\
Railway & 82,3 & 77,3 & $\mathbf{7 7 , 9}$ & $-5,0$ \\
Mining and coal & 73,0 & 75,0 & $\mathbf{7 4 , 4}$ & 2,0 \\
Chemical & 62,9 & 74,7 & $\mathbf{7 3 , 0}$ & 11,8 \\
Non-rail transport & 53,0 & 74,3 & $\mathbf{7 2 , 6}$ & 21,3 \\
Gas and lighting & 77,9 & 70,0 & $\mathbf{7 1 , 1}$ & $-7,9$ \\
Machinery and equipment & 60,1 & 71,6 & $\mathbf{7 0 , 8}$ & 11,5 \\
Sea transport and ports & 62,1 & 70,3 & $\mathbf{6 9 , 1}$ & 8,2 \\
Lumber industry & 68,6 & 64,9 & $\mathbf{6 5 , 6}$ & $-3,7$ \\
Food, beverage and tobacco & 61,2 & 65,0 & $\mathbf{6 4 , 5}$ & 3,8 \\
Textile & 68,0 & 62,9 & $\mathbf{6 3 , 5}$ & $-5,1$ \\
\hline
\end{tabular}




\begin{tabular}{lcccc}
\hline Paper and graphic arts & 52,8 & 59,4 & $\mathbf{5 8 , 6}$ & 6,6 \\
Construction & 61,7 & 56,8 & $\mathbf{5 7 , 5}$ & $-4,9$ \\
Aeronautics & 28,6 & 58,6 & $\mathbf{5 4 , 5}$ & 30 \\
Services & 48,9 & 52,9 & $\mathbf{5 2 , 6}$ & 4,0 \\
Agriculture and cattle farming & 42,9 & 50,2 & $\mathbf{4 9 , 5}$ & 7,3 \\
TOTAL PATENTS & 64,0 & 67,7 & $\mathbf{6 7 , 3}$ & 3,7 \\
\hline
\end{tabular}

Source: See Table 2.

Even more interesting than the distribution of patents is to discover how the presence of foreign technology was structured in the different sectors ${ }^{58}$. By skimming Table 7, we can see that dependence on foreign innovations was well above average in the basic, heavy sectors -with more scientific or technical complexity- and which required heavier investments in research and development, such as metals, railway, arms, mining, energy (gas and electricity), communications, or (after 1878) the chemical industry, machinery and equipment or shipping. On the other hand, in sectors such as consumer goods, technologically simpler and requiring less capital, the percentages of inventions and national technical developments were greater, such as agriculture and animal husbandry, food industry, services sector, construction, paper, lumber and even the textile industry. Moreover, we observe that in the last quarter of the century, dependence on foreign technology increased considerably in almost all sectors, especially heavy industry, which once again is a clear indication of technological expansion during the second industrial revolution and of the massive arrival of patent applications from abroad. In some industries, such as chemicals or machinery and equipment, the national innovation processes were above average before the Restoration, due, as already explained, to the fact that much production was carried out in small cottage industries or workshops throughout the country with simple technologies; but the path towards corporate structures and more complex production, as a consequence of the new technological trajectories opened up during the last quarter of the 19th century, increased its dependence. Among the sectors which experienced a slight decrease in foreign technology after 1878 (although without completely losing their dependence) were railways, in which the protectionist turn, substituting imports for national production began to have its effects, and industries such as gas or textiles, more closely tied to the first industrial revolution. In summary, we can deduce that there was a dual technological structure, with national invention and innovation concentrated in the consumer goods sector, less capital-intensive and with less-complex technologies; while the large infrastructures and intermediate sectors depended almost completely on the transfer of foreign technology.

\section{Effectiveness and duration of patents.}

The last point to be analyzed in this study is the obligatory implementation of patents and the expiration dates of technology monopolies, both of which could reveal qualitative information on the efficiency of the system in promoting innovation and its real impact on the economy. As seen in Table 1, Spanish legislation has always stated that patented inventions must be exploited, that is, applied to the production system, or that patent would expire. The patentee had one year to put it into practice between 1826 and 1878, two between 1878 and 1902, and three years between 1902 and 1907, after which they would lose the monopoly, and the technical information would belong to the public domain. Between 1826 and 1835 the Administration did not consistently enforce this requirement, but in the mid-30's, then even more between 1849 and 1878, the government intervened actively to block invention and introduction patents which were 
left unimplemented. Once the patentee turned in his application, the Administration sent a delegate with a public clerk who witnessed the practice, and later reported the results, which were submitted to the Reales Juntas de Agricultura, Industria y Comercio a regional institution, or to the Real Conservatorio de Artes y Oficios (the Patent Office) in Madrid; organizations which, in addition, could commission experts to assure that patents were being exploited. The controls were rigorous, requiring national production, and not just importing the technology or the product, although sometimes it was sufficient proof to see the invention functioning, especially when it was technology which could not be manufactured in Spain. In any case, a detailed study of the implementation files demonstrates that documentation in this period was very reliable, enough to give us a clear impression of the degree to which patents led to innovation processes, regardless of whether they were based on imported techniques, whether they were later diffused, or whether or not they had a great impact on the economy ${ }^{59}$.

The laws of 1878 and 1902 continued to require proof of exploitation, but the justification system was simplified. First, the Conservatory delegated an engineer to test the implementation of the patent, and later, any industrial engineer contracted by the patentee. In both cases, posting the certificate, without notarization or later examinations, was sufficient for the renovation of the patent. That did not necessarily mean that the requirements were easier, but the analysis of documentation shows that, in many cases, engineers' certificates were very vague, referring to 'sufficient means' for the exploitation of a technology or the same workshops were mentioned time and again in relation to the implementation of the inventions, which indicates the relaxation of the system. However, there are many cases of truthful rendering of correct practices, and after 1878, expiration due to lack of implementation continued to be the main cause, which means that, to a certain degree, exploitation requirements continued to function as an important filter.

Once these requirements were met, the duration of the patent becomes the other important consideration in assessing the economic impact of the patent, supposing that its greater length and cost was a consequence of reasonable expectation of profit from the innovation which made it attractive to continue fighting off competitors. This type of information can be obtained from the study of initial and renovation fees paid by the applicant to maintain exclusives rights, which as previously explained, were paid in advance between 1826 and 1878 after choosing the expiration date (5, 10 or 15 years), and between 1878 and 1907 was paid annually for a maximum of 20 years (except for patents of introduction with a limit of 5 years). Therefore, between 1826 and 1878, confidence in the innovation's potential had to be calculated before taking out the patent, which produces a certain distortion, although we suppose that, since the 5-year invention patents could be renewed for another 5 years, applying directly for a 10 or 15 year patent indicates more confidence in the invention's possibilities. After 1878, however, it was much easier for patentees to abandon an unprofitable invention simply by not paying the fee, which we suppose occurred when the monopoly costs were greater than profits obtained. 
Table 8. Patent implementation and monopoly duration. Spain 1826-1907.

\begin{tabular}{|c|c|c|c|c|c|c|}
\hline 1826-1878 & & & & & & \\
\hline PATENTS & $\begin{array}{l}\text { Imple- } \\
\text { mented } \\
\%\end{array}$ & $\begin{array}{c}\text { Non imple- } \\
\text { mented } \\
\%\end{array}$ & $\begin{array}{c}\text { Effective- } \\
\text { ness index* }\end{array}$ & $\begin{array}{c}\text { Duration } \\
\leq 5 \text { years } \\
\%\end{array}$ & $\begin{array}{c}\text { Duration } \\
>5 \text { years } \\
\%\end{array}$ & $\begin{array}{c}\text { Persistence } \\
\text { index* }\end{array}$ \\
\hline AVERAGE FOR SPAIN & 25,6 & 74,4 & 1,00 & 90,8 & 9,2 & 1,00 \\
\hline Nationals & 34,7 & 65,3 & 1,36 & 89,1 & 10,9 & 1,18 \\
\hline Foreigners & 16,5 & 83,5 & 0,64 & 92,6 & 7,4 & 0,80 \\
\hline Invention & 23,3 & 76,7 & 0,91 & 88,2 & 11,8 & 1,28 \\
\hline Introduction & 33,4 & 66,7 & 1,30 & 100,0 & 0,0 & 0,00 \\
\hline Residents & 33,0 & 67,0 & 1,29 & 89,3 & 10,7 & 1,16 \\
\hline Non-residents & 12,6 & 87,4 & 0,49 & 93,5 & 6,5 & 0,71 \\
\hline Individuals & 24,6 & 75,4 & 0,96 & 90,9 & 9,1 & 0,99 \\
\hline Two or more individuals & 22,9 & 77,1 & 0,89 & 91,6 & 8,4 & 0,91 \\
\hline Corporations & 39,1 & 60,9 & 1,53 & 88,4 & 11,6 & 1,26 \\
\hline Civil servants & 26,6 & 73,4 & 1,04 & 89,8 & 10,2 & 1,11 \\
\hline Technicians, etc. & 23,4 & 76,6 & 0,91 & 86,9 & 13,1 & 1,42 \\
\hline Manufacturers, etc. & 30,9 & 69,1 & 1,21 & 90,6 & 9,4 & 1,02 \\
\hline Machinery / Equipment & 23,3 & 76,7 & 0,91 & 89,3 & 10,7 & 1,16 \\
\hline Services & 23,3 & 46,7 & 0,91 & 94,0 & 6,0 & 0,65 \\
\hline Textile & 35,7 & 64,3 & 1,39 & 92,5 & 7,8 & 0,85 \\
\hline Food, beverage, etc. & 25,5 & 74,5 & 1,00 & 88,4 & 11,6 & 1,26 \\
\hline Chemical & 28,6 & 71,4 & 1,12 & 90,6 & 9,4 & 1,02 \\
\hline Basic metals & 26,2 & 73,8 & 1,02 & 89,0 & 11,0 & 1,20 \\
\hline Electricity & 9,1 & 90,9 & 0,36 & 100,0 & 0,0 & 0,00 \\
\hline Construction & 31,5 & 68,5 & 1,23 & 88,0 & 12,0 & 1,30 \\
\hline Paper and graphic arts & 24,3 & 75,7 & 0,95 & 90,2 & 9,8 & 1,07 \\
\hline Railway & 12,0 & 88,0 & 0,47 & 92,6 & 7,4 & 0,80 \\
\hline \multicolumn{7}{|l|}{ 1878-1907 } \\
\hline PATENTS & $\begin{array}{c}\text { Imple- } \\
\text { mented } \\
\%\end{array}$ & $\begin{array}{c}\text { Non imple- } \\
\text { mented } \\
\%\end{array}$ & $\begin{array}{c}\text { Effective- } \\
\text { ness index* }\end{array}$ & $\begin{array}{c}\text { Duration } \\
\leq 5 \text { years } \\
\%\end{array}$ & $\begin{array}{c}\text { Duration } \\
>5 \text { years } \\
\%\end{array}$ & $\begin{array}{c}\text { Persistence } \\
\text { index* }\end{array}$ \\
\hline AVERAGE FOR SPAIN & 28,3 & 71,7 & 1,00 & 87,8 & 12,2 & 1,00 \\
\hline Nationals & 22,0 & 78,0 & 0,78 & 93,0 & 7,0 & 0,57 \\
\hline Foreigners & 32,7 & 67,3 & 1,16 & 84,3 & 15,7 & 1,29 \\
\hline Invention & 28,0 & 72,0 & 0,99 & 85,4 & 14,6 & 1,20 \\
\hline Introduction & 28,3 & 71,7 & 1,00 & 100,0 & 0,0 & 0,00 \\
\hline Residents & 22,4 & 77,6 & 0,79 & 92,8 & 7,2 & 0,59 \\
\hline Non-residents & 32,9 & 67,1 & 1,16 & 84,1 & 15,9 & 1,30 \\
\hline Individuals & 25,8 & 74,2 & 0,91 & 89,1 & 10,9 & 0,89 \\
\hline Two or more individuals & 26,3 & 73,7 & 0,93 & 89,1 & 10,9 & 0,89 \\
\hline Corporations & 40,2 & 59,8 & 1,42 & 81,8 & 18,2 & 1,49 \\
\hline
\end{tabular}




\begin{tabular}{lcccccc}
\hline Civil servants & 24,3 & 75,7 & $\mathbf{0 , 8 6}$ & 89,8 & 10,2 & $\mathbf{0 , 8 4}$ \\
Technicians, etc. & 32,9 & 67,1 & $\mathbf{1 , 1 6}$ & 84,1 & 15,9 & $\mathbf{1 , 3 0}$ \\
Manufacturers, etc. & 31,5 & 68,5 & $\mathbf{1 , 1 1}$ & 86,8 & 13,2 & $\mathbf{1 , 0 8}$ \\
& & & & & & \\
Machinery / Equipment & 28,3 & 71,7 & $\mathbf{1 , 0 0}$ & 87,2 & 12,8 & $\mathbf{1 , 0 5}$ \\
Services & 19,7 & 80,3 & $\mathbf{0 , 7 0}$ & 92,6 & 7,4 & $\mathbf{0 , 6 1}$ \\
Textile & 28,1 & 71,9 & $\mathbf{0 , 9 9}$ & 89,2 & 10,8 & $\mathbf{0 , 8 9}$ \\
Food, beverage, etc. & 28,1 & 71,9 & $\mathbf{0 , 9 9}$ & 88,5 & 11,5 & $\mathbf{0 , 9 4}$ \\
Chemical & 33,2 & 66,8 & $\mathbf{1 , 1 7}$ & 85,9 & 14,1 & $\mathbf{1 , 1 6}$ \\
Basic metals & 35,5 & 64,5 & $\mathbf{1 , 2 5}$ & 84,3 & 15,7 & $\mathbf{1 , 2 9}$ \\
Electricity & 34,7 & 65,3 & $\mathbf{1 , 2 3}$ & 85,2 & 14,8 & $\mathbf{1 , 2 1}$ \\
Construction & 27,7 & 72,3 & $\mathbf{0 , 9 8}$ & 89,8 & 10,2 & $\mathbf{0 , 8 4}$ \\
Paper and graphic arts & 26,8 & 73,2 & $\mathbf{0 , 9 5}$ & 88,8 & 11,2 & $\mathbf{0 , 9 2}$ \\
Railway & 29,9 & 70,1 & $\mathbf{1 , 0 6}$ & 86,0 & 14,0 & $\mathbf{1 , 1 5}$ \\
\hline
\end{tabular}

* The effectiveness index is the quotient of the percentage of patents implemented in each category above the national average. So, the persistence index is the quotient of the percentage of patents greater than 5 years in each category above the national average.

Source: See Table 2.

As seen in Table 8, between 1826 and 1907 only 25-28\% of registered patents were implemented, and although that does not mean that those which were not approved did not eventually take part in innovative processes, we can affirm that $75 \%$ of registered inventions lost their monopoly rights within 3 years, transferring that technical information to the public domain. Moreover, if we observe duration data for the entire period studied, we see that approximately $88-91 \%$ of all patents had expired within 5 years; that is, only $10 \%$ of patents were maintained longer than 5 years, and theoretically, had a consistent impact on the economy. This also means that many 'officially' implemented patents were abandoned after two or three years, probably due to lack of profits or just because they had not become real innovations. In general, only $4 \%$ lasted 10 years, and less than $2 \%$ lasted an average of 15 years during the 19th century, which appears to indicate that the real economic impact of patents in Spain was, at most, short-term.

Crossing these data with the different categories analyzed throughout the work in an attempt to discover which factors could influence the implementation and duration of patents, we would like to point out, first, the existence of two clearly different periods in the use and functioning of the system. Through the analysis of the 'effectiveness' and 'persistence' indexes found in Table 8, we see that during the first three-fourths of the 19th century, national patents were implemented more often than foreign ones, those of residents more often than non-residents, introduction patents were more successful than invention patents, enterprises more than individuals, and manufacturers and craftsmen more than any other profession. With respect to the economic sectors with greater patent implementation before 1878, consumer goods, such as the textile industry, construction, food, and simple chemical production appeared to be the most successful. The ideal applicant, therefore, would be a Spanish manufacturer, company or craftsman, in charge of an industrial shop dedicated to producing final products, for example textiles, in direct contact with the production system, cautiously applying for introduction patents based on previously-tested foreign technologies, living in Catalonia or another well-connected port city. Similar conditions prevail when the patent is extended beyond 5 years, with the obvious exception of those with the built-in time limit. However, worth noting is that technicians, engineers and 
qualified professionals tended to solicit long-term patents, undoubtedly demonstrating extreme persistence and confidence in their inventions as opposed to the below-average effectiveness index assigned to them and the maximizing of costs and profits by craftsmen and entrepreneurs. In those sectors where patents has a longer-than-average duration, construction and the food industry stand out, together with heavier industries, such as basic metals and machinery and equipment -in which the type of technology employed would take time to write off ${ }^{60}$ - and patents were more short-term in the textile industry or the services sector.

But if we focus on the last quarter of the 19th century and the beginning of the 20th century, the most influential factors leading to implementation or in the duration of the patent were substantially different from earlier periods. So, for example, after 1878, foreign patentees were more effective than domestic ones, and non-residents patentees more than resident ones. Companies continued being more successful with innovations than individuals, but engineers and technicians have increased their effectiveness even surpassing the level reached by manufacturers and entrepreneurs. Additionally, the sectors with greater success in obtaining innovations from patents were those of heavy industry, marked by the technologies of the second industrial revolution, such as basic metals, electricity, railways, chemicals or machinery and equipment, with consumer industries falling below average. Now the most successful applicant in attaining patents has become an industrial firm, a non-resident foreign engineer or a manufacturer, who sought patents of invention for complex technological advances in basic industries. Moreover, the factors cited were the same for the longer-than-average protections. At the end of the 19th century, therefore, inventive and innovate activity in the Spanish patent system had acquired features typical of the second industrial revolution model, with greater participation in an international superstructure closely linked to the recently emerging technological paradigm, in which new technological systems were forged and domestic impetus was at a minimum.

\section{Conclusion}

This study has attempted to carry out an in-depth analysis of the development of inventive and innovative activity in Spain during the first industrialization process in the country, using information found in the patent system. It is well known that this is an imperfect indicator and entails several problems, but due, among other things, to its historical availability, we consider it to be an interesting source for tracing the direction and characteristics of investment in new technologies. To accomplish this, we studied the institutional and legal considerations surrounding industrial property, where we observed that Spain organized a hybrid system of protection which maintained, for almost two centuries, the early French tradition. We call this hybrid because, although it protected original inventors, since it respected priority rights, issued long-term patents and prosecuted fraud, it also promoted the recording and implementation of third-party technologies in the country through patents of introduction, the concession without a technical or novelty examination and the obligation to exploit the invention within national territory. That is, there was an attempt to combine respect for intellectual property with the practical policy of facilitating innovation processes in order to favour industrial development and compensating a backward economy, which was not very different from other follower or latecomer countries for most of the $19^{\text {th }}$ century. So in the same way that protectionism was a fundamental growth strategy for many countries, permissiveness in allowing the introduction and imitation of foreign technologies could also have played and important role in the processes of modernization of several 
countries, while economic theory praises, at the same time, the benefits of free trade and those of intellectual property rights.

The detailed analysis of statistics and documentation of patents between 1770 and 1907 permits the characterization of the system and points out, above all, the strong and increasing dependence on foreign technology, which coincides with the general impression of historians specialized in innovation processes in Spain. We see that the direct participation of foreign applicants between 1851 and 1878 was over 50\% and continued to increase during the final quarter of the $19^{\text {th }}$ century, which, together with the existence of Spanish patents of introduction, was an imposing percentage of foreign technologies, close to $70 \%$. Moreover, individual petitions were more numerous than those of companies and firms, and most applicants were master craftsmen, craftsmen, manufacturers and businessmen in charge of small-scale productions, while qualified professionals and engineers were scarce before 1878 (although they increased their participation after that year), which in general indicates fairly simple technologies and demand-driven incremental innovations. On the other hand, on examining the places of residence of resident inventors (some of which were foreigners before 1878), we observe inventive and innovative activity closely related to the process of formation and integration of the Spanish market, confirming K. Sokoloff's classic hypothesis, and, once again, the influence of demand forces. The distribution of patents according to different economic sectors reinforces this impression, since the principal users of the system, together with industries normally associated with processes of technical changes (textile, metal, etc.), were a large group of productive activities related to the food, beverage and tobacco industries, the services sector or construction, closely related to consumption and responding quickly to market conditions. It was in these sectors that domestic inventive activity was concentrated, while foreign presence was close to $80 \%$ in infrastructure and heavy industry.

However, this general impression of the patent system must be qualified. Throughout the study we have found interesting differences in the functioning and utilization of industrial property in the first three-fourths of the 19th century, in contrast to the final period. So, for example, between 1878 and 1907, the most outstanding characteristics began to crystallize -see the presence of non-resident foreigners in the system- while others were revived and transformed, such as the important increase in participation of companies and engineers as recipients of patents or the tremendous advances with respect to machinery and equipment industries. This avalanche of applications by non-resident foreigners was due, in addition to the demand forces of the Spanish market and to institutional changes, to international patent strategies in the global technology market, which, to a degree, could clearly be thought of as a supplyside conditioned factor, as least in a scientifically backward country at the moment of the birth of a new technological paradigm. The analysis of data with respect to the implementation and duration of patents confirms the duality of the system before and after 1878, pointing out that during the first three quarters of the century, the most effective and persistent applicants were domestic, residents, craftsmen or manufacturers who solicited consumer-related patents of introduction, while between 1878 and 1907, just the opposite occurred; that is, non-resident foreigners, engineers and technicians, were more effective in implementing the patents and retaining the monopoly of complex technologies in heavy industry. The firms were always more effective and persistent than individual applicants. Although demand forces and incremental innovations from learning by doing -or using- governed the patent system before 1878, after that date, we must take into account radical patents that opened new technological trajectories 
(electricity, combustion engines, etc.) and foreign-induced supply and availability of techniques and energies.

\section{Notes and References}

${ }^{1}$ SCHUMPETER, J. A., Theory of Economic Development: An Inquiry Into Profits, Capital, Credit Interest and the Business Cycle, (Cambridge, Massachusetts, 1911) and SCHUMPETER, J. A., Business Cycles. A Theoretical, Historical and Statistical Analysis of the Capitalist Process, (New York, 1939). See also KUZNETS, S. S. Secular Movements in Production and Prices. Their Nature and Their Bearing Upon Cyclical Fluctuations, (Boston, 1930) and KUZNETS, S. S., 'Equilibrium Economics and Business Cycle Theory', The Quarterly Journal of Economics, vol. 44, (1930), 381-415.

2 SCHMOOKLER, J., 'Economic Sources of Inventive Activity', Journal of Economic History, vol. XXII, $\mathrm{n}^{\circ}$ 1, (1962), 1-20 and SCHMOOKLER, J., Invention and Economic Growth, (Cambridge, Massachusetts, 1966).

${ }^{3}$ ROSENBERG, N., 'The directions of Technological Change: Inducement Mechanisms and Focusing Devices’ in N. ROSENBERG (Ed.), Perspectives on Technology, (Cambridge, 1976), chapter 6, and ROSENBERG, N., Inside the Black Box: Technology and Economics, (Cambridge, 1982). See also MOKYR, J., 'Demand versus Supply in the Industrial Revolution', Journal of Economic History, vol. XXXVII, n 4, (1977), 981-1008.

${ }^{4}$ So, for example, K. ARROW dealt with the subject of inventive and innovative activity as a special field of the economics of information [see 'Economic Welfare and the Allocation of Resources for Invention' in R. R. NELSON (Ed.), The Rate and Direction of Inventive Activity, (New York, 1962), 609-625], this being discussed by K. PAVITT in his explanation of the influence of know-how and of the apprenticeship processes ['Technology Transfer among the Industrially Advanced Countries: An Overview' in N. ROSENBERG and C. FRISCHTADK (Eds.), International Technology Transfer: Concepts, Measures and Comparisons, (New York, 1985)]. S. Cheung approached this subject with a panoramic view of the economics of property rights - developed by R. Coase, A. Alchian or H. Demsetz- and on the institutional incentives for invention, clearly explained by D. North [see CHEUNG, S. 'Property Rights in Trade Secrets’, Economic Inquiry, no 20, (1982), 40-52]. Others, such as P. DASGUPTA, have used the possibilities of game theory to reflect on the issue [see 'Patents, Priority and Imitation or the Economics of Races and Waiting Games’, Economic Journal, nº 98, (1988), 66-80]; while R. Nelson, S. Winter o P. David, among others, have situated the problem of technological change within the central focus of the analysis of more recent economic tendencies, such as evolutionary economics or the theories of pathdependence [see NELSON, R. R. and WINTER, S. G., An Evolutionary Theory of Economic Change, (Cambridge, Massachusetts, 1982) and DAVID, P. A., 'Clio and the Economics of QWERTY', American Economic Review, vol. LXXV, n 2, (1985), 459-467].

${ }^{5}$ Only some general references: HABAKKUK, H., American and British Technology in the $19^{\text {th }}$ Century, (Cambridge, 1962); LANDES, D. S., The Unbound Prometheus: Technological Change and Industrial Development in Western Europe from 1750 to the Present, (Cambridge, Massachusetts, 1969); NORDHAUS, W. D., Invention, Growth and Welfare, (Cambridge, 1969); ROSENBERG, N., Technology and American Economic Growth, (New York, 1972); DAVID, P. A., Technical Choice, Innovation and Economic Growth: Essays on British and American Experience in the Nineteenth Century, (London, New York, 1975); HIGONNET, P., LANDES, D. S. and ROSOVSKY, H. (Eds.), Favourites of Fortune. Technology, Growth, and Economic Development since the Industrial Revolution, (Cambridge, Massachusetts, 1991); MATHIAS P. and DAVIS J. (Eds.), Innovation and Technology in Europe. From the Eighteenth Century to the Present Day, (Oxford \& Cambridge, Massachusetts, 1991); VON TUZELMANN, G. N., Technology and Industrial Progress. The Foundations of Economic Growth, (Aldershot, 1995); INKSTER, I. E., Technology and Industrialization: Historical Case Studies and International Perspectives, (Aldershot, Brookfield, 1998); BERG, M. and BRULAND, K. (Eds.), Technological Revolutions in Europe: Historical Perspectives, (Cheltenham, 1998); and CANTWELL, J., The History of Technological Development in Europe and the United States, (Oxford, forthcoming).

${ }^{6}$ For example, some, such as K. SOKOLOFF, demonstrated the close relationship between inventive and innovative activity and the formation and integration of markets, which, to a certain degree, confirms the idea that economic growth itself accelerates the process [see 'Inventive Activity in Early Industrial America: Evidence from Patent Records (1790-1846)', Journal of Economic History, vol. 48, n 4, (1988), 363-378]. Others, such as G. Von Tunzelmann have tried to point out the weaknesses in Schmookler's thesis with his own data [VON TUNZELMANN, G. N., 'Technology Generation, Technology Use and Economic Growth', European Review of Economic History, n ${ }^{\circ} 4$, (2000), 121-146]; and others, without 
denying the importance of demand, have insisted, from Neo-Schumpeterian and evolutionary standpoints, on aspects related to technology supply and innovation cycles [see ANDERSEN, B., Technological Change and the Evolution of Corporate Innovation. The Structure of Patenting, 1880-1990, (Cheltenham, Northampton, 2001).

${ }^{7}$ The use of I+D expenditure as an index presents many different problems. On the one hand, it is only available in very recent times and it represents only a part of the efforts in technical development. On the other hand, it is difficult to calculate the investments of small enterprises and, moreover, I+D expenditure may not directly lead to innovation. See COHEN, W. M. and LEVINTHAL, D. A., 'Innovation and Learning: The Two Faces of R\&D’, Economic Journal, no 99, (1989), 569-596.

${ }^{8}$ This system emerges as a consequence of the works of R. M. SOLOW, 'Technical Change and the Aggregate Production Function', Review of Economics and Statistics, $n^{\circ}$ 39, (1957), 312-320 on changes in the aggregate production function. This has been questioned to a great extent by evolutionary economists, by proving that technology does not always go along with productivity: See DAVID, P. A., 'The Dynamo and the Computer: An Historical Perspective on the Modern Productivity Paradox', American Economic Review Proceedings, n ${ }^{\circ}$ 80, (1990), 355-361 and VON TUNZELMANN, G. N., 'Technology Generation...', (2000).

${ }^{9}$ Apart from the lack of historical sources on the matter, bibliometric data coming from scientific publications are not really a good indicator, as they have more to do with advances in basic science than with technology. See ANDERSEN, B., Technological Change..., (2001), 20.

${ }^{10}$ We can find an original example in MOSER, P., How Do Patents Laws Influence Innovation? Evidence from Nineteenth-Century World Fairs, University of California,

http://elsa.berkeley.edu/ eichengr/PetraMoser.pdf, (Berkeley, 2001). However, there are not many data of this type from a historical point of view.

${ }^{11}$ It is true that the use of patents has created controversy [see GRILICHES, Z., 'Patent Statistics as Economic Indicators', Journal of Economic Literature, vol. 28, (1990), 1661-1707], since, in the first place, their study only reflects a portion of innovation while not capturing what is not registered (whether the results of national inventive activity, or technology imports or of changes in organization and of know-how that cannot be patented); secondly, a significant percentage of patents have never been exploited nor become real innovations in the economy, which complicates their role as a technological indicator; and, finally, the institutional diversity of patent laws has made international comparisons more difficult. However, patents have certain advantages over other indicators: there are continuous historical series which go back to the beginning of the $19^{\text {th }}$ century in several countries -many of them could be grouped into 'legal families' with similar institutional characteristics [see LERNER, J., '150 Years of Patent Protection', NBER Working Paper Series, $n^{\circ} 7478$, (2000) and LERNER, J., ' 150 Years of Patent Office Practice', NBER Working Paper Series, $\left.n^{\circ} 7477,(2000)\right]-$; patents are, in general, a good indicator of investment in new technologies within a specific economy, whether or not they are successful or the registered object becomes an innovation or is never exploited (the same occurs with capital investments) [see SÁIZ, J. P., Invención, patentes e innovación en la España contemporánea, (Madrid, 1999), 100103]; patents are a gauge of the role that 'human effort' plays in the development of certain technologies [see VON TUNZELMANN, G. N., and ANDERSON, E., 'Technologies and Skills in Long-run Perspective', Mimeo, SPRU/IDS (Sussex, 1999)]; patents are also a partial technological indicator, which, for many, is superior to any other types of data [see ANDERSEN, B., Technological Change.... (2001), chapter II]; and finally, patents have given rise to a very rich historical documentation which could supply complementary panoramic views of the problem of innovation and economic growth if it is studied deeply. Therefore, in spite of discordant voices [see, for example, GRIFFITHS, T., HUNT, P. A. and O’BRIEN, P. K., 'Inventive Activity in the British Textile Industry, 1700-1800', Journal of Economic History, vol. 52, nº, (1992), 881-906, and O’BRIEN, P. K., GRIFFITHS, T. and HUNT, P. A., 'There Is Nothing Outside the Text and There Is No Safety in Numbers: A Reply to Sullivan', Journal of Economic History, vol. 55, $\mathrm{n}^{\circ} 3$, (1995), 671-672] it is not surprising that there has been much research on patent systems and on what they add to economic history: Apart from the above-mentioned works of B. ANDERSEN; E. ANDERSON; I. E. INKSTER; J. P. SÁIZ; J. SCHMOOKLER; K. L. SOKOLOFF and G. N. VON TUNZENLMANN, see, on United Kingdom DUTTON, H., The Patent System and Inventive Activity during the Industrial Revolution 1750-1852, (Manchester, 1984); MACLEOD, Ch., Inventing the Industrial Revolution. The English Patent System, 1660-1800, (Cambridge, 1988); MACLEOD, Ch., 'The Paradoxes of Patenting: Invention and Its diffusion in 18th- and 19th- Century Britain, France, and North America', Technology and Culture, vol. 32, n ${ }^{\circ}$ 4, (1991), 885-910; MACLEOD, Ch., 'Strategies for Innovation: The Diffusion of New Technology in Nineteenth-Century British Industry', Economic History Review, vol. XLV, $n^{\circ}$ 2, (1992), 285-307; MACLEOD, Ch., 'Concepts of Invention and the Patent Controversy in Victorian Britain' in R. FOX, (Ed.), Technological Change: Methods and Themes in the 
History of Technology, (Amsterdam, 1996); MACLEOD, Ch., 'Negotiating the Rewards of Invention: The Shop-Floor Inventor in Victorian Britain', Business History, vol. 41, nº 2, (1999), 17-36; SULLIVAN, R. J., 'The Revolution of Ideas: Widespread Patenting and Invention during the English Industrial Revolution', Journal of Economic History, vol. L, $\mathrm{n}^{\circ}$ 2., (1990), 349-362, and SULLIVAN, R. J., 'Patent Counts and Textile Invention: A comment on Griffiths, Hunt and O’Brien', Journal of Economic History, vol. LV, $\mathrm{n}^{\circ} 3$, (1995), 666-670; on USA PHILLIPS, W. H., 'Patent Growth in the Old Dominion: The Impact of Railroad Integration before 1880', Journal of Economic History, vol. LII, $n^{\circ}$ 2, (1992), 389-400; KHAN, B. Z. and SOKOLOFF, K. L., 'Patent Institutions, Industrial Organization and Early Technological Change: Britain and the United States, 1790-1850’ in M. BERG and K. BRULAND (Eds.), Technological Revolutions..., (1998); KHAN, B. Z., 'Property Rights and Patent Litigation in Early Nineteenth Century America', Journal of Economic History, vol. LV, n ${ }^{\circ}$ 1, (1995), 58-97; KHAN, B. Z. and SOKOLOFF, K. L., 'Schemes of Practical Utility: Entrepreneurship and Innovation Among "Great Inventors" in the United States, 1790-1865', Journal of Economic History, vol. LVIII, (1993), 289-307; LAMOREAUX, N. R. and SOKOLOFF, K. L., 'Inventors, Firms, and the Market for Technology in the Late Nineteenth and Early Twentieth Centuries' in N. R. LAMOREAUX et al. (Eds.), Learning by doing in Markets, Firms and Countries, (Chicago, 1999), and SOKOLOFF, K. L. and KHAN, B. Z., 'The Democratization of Invention During Early Industrialization: Evidence from the United States, 1790-1846, Journal of Economic History, vol. L, n ${ }^{\circ}$ 2, (1990), 363-378; on France HILAIRE-PEREZ, L., 'Invention and the State in 18th-Century France', Technology and Culture, vol. 32, n 4, (1991), 911-931; on Norway BASBERG, B. L., 'Foreign Patenting in the U.S. as a Technology Indicator. The Case of Norway', Research Policy, $\mathrm{n}^{\circ}$ 12, (1983), 227-237, and BASBERG, B. L., 'Patent Statistics and the Measurement of Technological Change. An Assessment of the Norwegian Patent Data, 1840-1980', World Patent Information, vol. 6, no 4, (1984) 158164; on Spain SÁIZ, J. P., Propiedad industrial y revolución liberal. Historia del sistema español de patentes (1759-1929), (Madrid, 1995); SÁIZ, J. P., Legislación histórica sobre propiedad industrial. España (1759-1929), (Madrid, 1996); SÁIZ, J. P., 'Patentes, cambio técnico e industrialización en la España del siglo XIX’, Revista de Historia Económica, nº 2, (1999), 265-268; ORTIZ-VILLAJOS, J. M., Tecnología y desarrollo económico en la Historia Contemporánea, (Madrid, 1999), and ORTIZ-

VILLAJOS, J. M., 'Tecnología y desarrollo regional en España, 1882-1935. Un estudio basado en las patentes de invención', Revista de Historia Económica, $n^{\circ}$ 1, (1999), 11-48; on Italy VASTA, M., Innovazione tecnologica e capitale umano in Italia (1880-1914): le traiettorie della seconda rivoluzione industriale, Il Mulino, (Bologna, 1999) and on Mexico BEATTY, E., Institutions and Investment: The Political Basis of Industrialization in Mexico before 1911, (Stanford, 2001). International comparisons in INKSTER, I. E., 'Technology Transfer in the Great Climacteric. Machinofacture and International Patenting in World Development circa 1850-1914', History of Technology, vol. 21, (1999), 87-106; INKSTER, I. E., 'Machinofacture and Technical Change: the Patent Evidence 1850-70', in I. E. INKSTER et al. (Eds.), The Golden Age. Essays in British Social and Economic History 1850-1870, (London, 2000), 121-139; INKSTER, I. E., 'Patents as Indicators of Technological Change and Innovation. An Historical Analysis of the Patent Data 1830-1914', London Meeting of the Newcomen Society for the History of Engineering, (London, 2002) and INKSTER, I. E., 'Finding Artisans. British and International Patterns of Technological Innovation, 1790-1914', Cahiers d'Histoire et de Philosophie des Sciences: Artisans, industrie. Nouvelles révolutions du Moyen Âge à nos jours, (Paris, Lyon, forthcoming).

${ }^{12}$ KHAN, B. Z., 'Property Rights...', (1995): the stronger the patents are, the greater the tendency to register inventions is. To this effect, see MOSER, P., How Do Patents..., (2001): the more lasting and efficient a patent is, the greater its value.

${ }^{13}$ The project is directed by Dr. J. P. Sáiz González and Dr. F. Cayón García. The following people have taken part in it as researchers from 1999 to 2002: Luis Blázquez Morales, Raúl Chamorro Cobo, Rafael Illescas Rojas, Juan Carlos García González, Joan González-Bueno Uribe, Pablo Gutiérrez Astilleros, Francisco Llorens Acien, Inmaculada Lozano Caro, Jesús David Martín Álvarez, Alberto Martín Ruiz, Jorge Morales de Castro, Vanessa Moreno Vincent, Susana Ortega Vázquez, Esther Riaza González, Elena Ruiz Labrador, Carlos Sánchez Díez and Gorka Villar Parra.

${ }^{14}$ The British Statute of Monopolies of 1624 or the French Déclaration du Roi concernant les privilèges en fait de commerce of 1762. See MACLEOD, Ch., Inventing the Industrial..., (1988), 16-18 and SAVIGNON, F., 'La Révolution Française et les brevets d'invention', La Propiété Industrielle, WIPO, $\mathrm{n}^{\circ}$ 11, (1989), 416-417.

${ }^{15}$ GARCÍA TAPIA, N., 'Los orígenes de las patentes de invención’ in F. AYALA CARCEDO (Coord.), Historia de la tecnología en España, (Barcelona, 2001), t. II, 90-94. See also GARCÍA TAPIA, N., Patentes de invención españolas en el Siglo de Oro, (Madrid, 1990).

${ }^{16}$ Royal Decree of September, $16^{\text {th }}$, 1811; Gaceta de Madrid September $24^{\text {th }}, 1811$. 
${ }^{17}$ Patents Law, January $7^{\text {th, }} 1791$ : See PLASSERAUD, Y. and SAVIGNON, F., L'État et l'invention: histoire des brevets, (Paris, 1986), 186.

${ }^{18}$ Archivo Histórico Nacional, Estado, Leg. 164.

${ }^{19}$ Decretos del Rey Nuestro Señor D.Fernando VII, y Reales Ordenes, Resoluciones y Reglamentos generales expedidos por las Secretarías del despacho universal y Consejos de S. M, 1826, (Tomo X).

${ }^{20}$ Colección Legislativa de España, t. CXIX.

${ }^{21}$ Colección Legislativa..., nueva serie, t. XII.

${ }^{22}$ Colección Legislativa..., nueva serie, t. CXV

${ }^{23}$ Boletín Oficial del Estado. March $26^{\text {th }} 1986, n^{\circ} 73$.

${ }^{24}$ For a complete analysis of patents legislation see: SÁIZ, J. P., Propiedad industrial..., (1995). The aforementioned legislation has been reproduced in SÁIZ, J. P., Legislación histórica..., (1996), together with every other patent law up to 1929.

${ }^{25}$ See SÁIZ, J. P., Invención, patentes..., (1999), 133-137. In relation to prices and salaries see MALUQUER DE MOTES, J., 'Precios, salarios y beneficios. La distribución funcional de la renta' in A. CARRERAS (Coord.), Estadísticas Históricas de España. Siglos XIX y XX, (Madrid, 1989), 499-527; RODRÍGUEZ LABANDEIRA, J., El trabajo rural en España (1876-1936), (Barcelona, 1991), 290 and following; SOTO CARMONA, A., El trabajo industrial en la España contemporánea (1874-1936), (Barcelona, 1989), 509-581.

${ }^{26}$ The more efficient the patent against usurpers is, the greater value they have for the patentee and the greater incentive its procurement represents: KHAN, B. Z., 'Property Rights...', (1995). A longer duration increases the value of the patent: GILBER, R. and SAPHIRO, C., 'Optimal Patent Length and Breadth', RAND Journal of Economics, vol. 21, $\mathrm{n}^{\circ} 1$, (1990), 106-112. In relation to the effects of patent duration on innovation processes, see MOSER, P., How Do Patents..., (2001), 6-7 and 49-51.

${ }^{27}$ Whenever it was possible, the calculations have been taken from patent applications rather than from concessions. Those of the United Kingdom are from 1852, those of France, Germany and the USA are from 1884, according to WIPO, 100 years of Industrial Property Statistics, (Geneve, 1983) and FEDERICO, P. J., 'Historical Patent Statistics 1791-1961', Journal of the Patent Office Society, vol. 46, $\mathrm{n}^{\circ} 2$, (1964), 83-171. In Spain, the greater part of applications were accepted, while in the USA, Germany and the UK the amount varies between $35 \%$ and $65 \%$ depending on the periods. For more details on patent statistics as well as for an exhaustive international comparison throughout the 19th and 20th centuries see SÁIZ, J. P., Invención, patentes..., (1999), chapter II.1 and SÁIZ, J. P., 'Patents, International Technology Transfer and Spanish Industrial Dependence (1759-1878)' in L. HILAIREPÉREZ and A. F. GARÇON (Eds.), Les chemins de la nouveauté. Innover, inventer au regard de l'histoire, (Paris, forthcoming), appendix.

${ }^{28}$ It lasted only until 1869, as the patent system was eliminated between 1869 and 1912.

${ }^{29}$ KHAN, B. Z. and SOKOLOFF, K. L., in 'Patent Institutions...', (1998), have proved how the fall of patent rates in the USA and the United Kingdom between 1790 and 1850 exerted a positive influence on registration tendencies.

${ }^{30}$ A detailed study on foreign technological transfer in Spain before 1878 can be found in SÁIZ, J. P., 'Patents, International...', (forthcoming).

${ }^{31}$ For technological transfer to Spain within the last quarter of the $19^{\text {th }}$ century see SÁIZ, J. P., 'Transferencia tecnológica internacional hacia España a través del sistema de patentes (1759-1900)' in Congreso Internacional: Las transferencias tecnológicas a largo plazo en el ámbito mediterráneo, Montecatini, SISE, AFHE, AHE and APHES, 9-11 November 2001, (Paris, forthcoming).

${ }^{32}$ Concerning the nationality of enterprises that used to have investments in Spain during the $19^{\text {th }}$ century and the beginning of the $20^{\mathrm{th}}$ century, see TORTELLA, T., A Guide to Sources of Information on Foreign Investment in Spain, 1780-1914, (Amsterdam, 2000), Tables 1 and 5, pp. xi and xix.

${ }^{33}$ Before 1878, 75\% of patents belonging to foreign residents in Spain were French, $14 \%$ were British; $4 \%$ were Italian and 2\% were German (SÁIZ, J. P., 'Patents, International...', forthcoming). From 1878 to 1900 French participation had dropped to $37 \%$, British participation was at $19 \%$, German $17 \%$, Italian 7,5 \%, and Belgian and Swiss was almost 5\% (SÁIZ, J. P., 'Transferencia tecnológica...', forthcoming).

${ }^{34}$ For a general view of railway history in Spain see COMÍN, F., MARTÍN ACEÑA, P., MUÑOZ, M. and VIDAL, J., 150 años de historia de los ferrocarriles españoles, (Madrid, 1998). See also GÓMEZ MENDOZA, A., Ferrocarriles y cambio económico en España, 1855-1913. Un enfoque de nueva historia económica, (Madrid, 1982).

${ }^{35}$ For ports development and maritime transport see SÁENZ, F., 'Evolution of Spanish Ports during the 19th Century' in CEHOPU, Spanish Ports Throughout History, (Madrid, 1994), 101-116; FRAX, E. and MATILLA, M. J., 'Transport and Maritime Trade during the $18^{\text {th }}$ and $19^{\text {th }}$ Centuries' in CEHOPU Spanish Ports Throughout History, (Madrid, 1994), 77-100, and VALDALISO, J. M., 'Growth and 
Modernization of the Spanish Merchant Marine, 1860-1935', International Journal of Maritime History, vol. III, $n^{\circ} 1$, (1991), 33-58.

${ }^{36}$ For banking development see TORTELLA, G. (Dir.), La banca española en la Restauración, (Madrid, 1974) and GARCÍA, J. R. 'El sistema bancario español del siglo XIX: ¿una estructura dual? Nuevos planteamientos y nuevas propuestas’, Revista de Historia Económica, vol. VII, (1989), 111-132.

${ }^{37}$ SOKOLOFF, K. L., 'Inventive Activity...’, (1988).

${ }^{38}$ Notice that between 1826 and 1850 a greater proportion of Spanish enterprises applied for patents than in the periods before and after (and also compared with foreigner applicants). This was the period in which Capitalism was born in Spain and, not only the patent system but also the Trade Code -which regulated the organization of companies- were established. Perhaps these first firms used the new patent system a little more trying to position themselves in the incipient market, especially by taking out patents of introduction for foreign technology, which were abundant in this period among Spaniards (see Table 2).

${ }^{39}$ For more details see SÁIZ, J. P., Invención, patentes..., (1999), 169-191.

${ }^{40}$ It is not problematic to include corporate patents in the analysis before 1878 , because 1 ) the sample we work with is quite large (74\% of the patents contain profession data) and 2) the enterprises were not only a few, but also small companies. Limited partnerships predominated (we have found only 79 incorporated companies) so we can classify them by their members' professions -among which the inventor is usually one of the partners- or include the companies in the group manufacturers, salesman..., of Table 5 without distorting the conclusions (see SÁIZ, J. P., Invención, patentes..., (1999), 160-191). But between 1878 and 1911, it is not possible to include the corporate patents without distorting the analysis because 1) the profession data is only included in $25 \%$ of individual patents while we know the data of $100 \%$ of enterprises; 2) the number of companies using the patent system have increased significantly in this period (see Table 4 of this article), especially large and industrial corporations, which makes impossible to classify them by their members' professions; and 3) corporate patents can no longer be included in the group c) manufacturers..., because, as it is known, in the second industrial revolution the enterprises owned patents which protected inventions from engineers and other skilled workers who were on the staff. Hence, Table 5 has been calculated only with individual patents, but we must bear in mind the mentioned corporate participation in the Spanish patent system at the end of the $19^{\text {th }}$ and the beginning of the $20^{\text {th }}$ century, which eventually may be worthwhile to study in detail.

${ }^{41}$ See ARROW, K. J., 'The Economic Implications of Learning by Doing', Review of Economic Studies, $n^{\circ}$ 29, (1962), 55-73 and ROSENBERG, N. Inside the Black Box: Technology and Economics, (New York, 1982), 131.

${ }^{42}$ See INKSTER, I. E., 'Patents as Indicators...' (2002), 9-14, and INKSTER, I. E., 'Finding Artisans...' (forthcoming).

${ }^{43}$ See SCHMOOKLER, J., Invention and Economic..., (1966), 20-23.

${ }^{44}$ GRILICHES, Z., 'Patent Statistics...', (1990).

${ }^{45}$ WIPO, International Patents Classification ( $5^{\text {th }}$ Edition), (Geneve, 1989).

${ }^{46}$ I must mention the great support and generous collaboration of Ruben Amengual and Gerardo Penas, which are examiner engineers of patents in OEPM, as well as the support given by the chemist Francisco Llorens, who has helped the group of researchers in classifying the patents.

${ }^{47}$ They protect novelties of different types concerning housing reorganization, furniture, private and domestic objects, urbanism, medicines, hygiene, heating, music, sport and plays, shows, teaching, fine arts, optics, photography, etc.

${ }^{48}$ They register different advances concerning flour grinding and production, pastries, pasta, canned fish, meat, vegetables, every kind of food item, ice production, alcoholic drinks, sugar refinement, edible oils, tobacco, etc.

${ }^{49}$ Including innovative activities within small production entities dedicated to manipulation of fats, oil, candles, soaps, cosmetics, glass, matches, medicines, fertilizers, lubricants, paints and varnishes, and other kinds of compounds of generic consumption.

${ }^{50}$ Including inventions in plaster production, cements, bricks, tiles, artificial stones, building structures, bridges, digging systems, perforation, stone cutting, new elements and materials, etc.

${ }^{51}$ It is in fact one of the main users of patents system. A general panorama of the Catalonian textile industry is available in MALUQUER, J., 'La estructura del sector algodonero en Cataluña durante la primera etapa de la industrialización, 1832-1861’, Hacienda Pública Española, nº 38, (1976), 133-148. 52 On the first Andalusian basic metals industry, see ALCALÁ-ZAMORA, J., 'Producción de hierro y altos hornos en la España anterior a 1850', Moneda y Crédito, $n^{\circ}$ 128, (1974), 117-218; and on the Basque Country see BILBAO, L. M., 'Renovación tecnológica y estructura del sector siderúrgico en el País Vasco durante la primera etapa de la industrialización (1849-1880)’, in J. M. GONZÁLEZ, J. 
MALUQUER and B. de RIQUER (Eds.), Industrialización y nacionalismo. Análisis comparativos, (Barcelona, 1985), 211-228.

${ }^{53}$ On capital goods industry in Spain and the arrival of foreign enterprises during the first thirty years of the 20th century see BETRÁN, C., 'La transferencia de tecnología en España en el primer tercio del siglo XX: el papel de la industria de bienes de equipo’, Revista de Historia Industrial, no 15, (1999), 41-81.

${ }^{54}$ Lately of interest to researchers. A first general overview was offered by NADAL, J. and CATALAN, J. (Eds.), La cara oculta de la industrialización española. La modernización de los sectores no líderes (siglos XIX y XX), (Madrid, 1994).

${ }^{55}$ Later on it was questioned by GRIFFITHS, T., HUNT, P. A. and O’BRIEN, P. K., 'Inventive Activity...', (1992); see SULLIVAN, R., 'The Revolution of Ideas...', (1990), 353-361, who has found 35\% of patents on food items, glass, construction, services, paper, arms, etc. at the height of the British industrial revolution.

${ }^{56}$ On railway patents see CAYÓN, F., FRAX, E., MATILLA, M. J., MUÑOZ, M. and SÁIZ, J. P., Vías paralelas. Invención y ferrocarril en España (1826-1936), (Madrid, 1998).

${ }^{57}$ For the arrival in Spain of the great European chemical industry see, for example, TOCA, A., 'Industria química y cambio tecnológico: el procedimiento electrolítico Solvay en Torrelavega', Quaderns d’Història de L'Enginyeria, vol. II, (1997), 43-76.

${ }^{58}$ Percentages of foreign technology in the different sectors between 1770 and 1878 may differ somehow from those given in other works [such as SÁIZ, J. P., 'Patents, International...' (forthcoming)]. It is due to the fact that, in this case, we only include patents and privileges, omitting other awards given for inventions between 1759 and 1826. Another fact to take into account is that, on this occasion, for our calculations, those applicants of unknown nationality have been considered as foreigners, as it is possible to assure that they are not Spanish, in spite of not knowing their country of origin.

${ }^{59}$ A detailed analysis of the requirements for patent practice between 1826 and 1878 and their reliability can be found in SÁIZ, J. P., Invención, patentes..., (1999), 199-213.

${ }^{60}$ Even though more than $80 \%$ of patents expired before the $6^{\text {th }}$ year of use, the duration of heavy industries patents tended to be greater than that of industries which are nearer to consumption. Principally, we can confirm this fact between 1878 and 1907. As a matter of fact, it partially coincides with some of the assertions of P. MOSER, How Do Patents..., (2001), 9-12, who points out how these sectors have longer innovation cycles, and how the possibility of obtaining patents for more than 10 years benefits the growth of their participation in the system. 